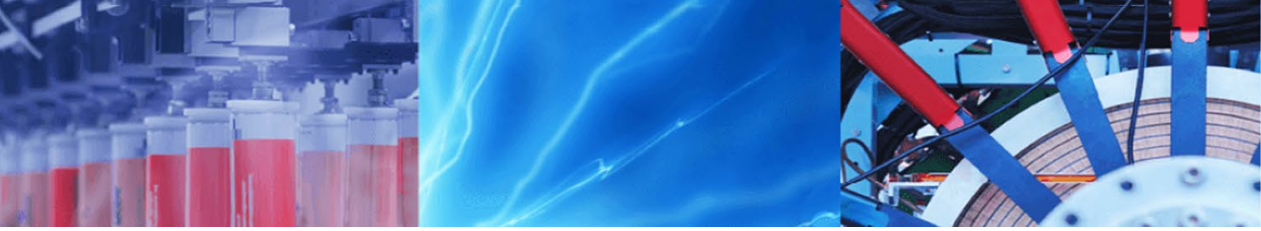

Research Article

\title{
Ru doping effect on the structural, electronic, transport, optical and dye degradation properties of layered $\mathrm{Li}_{2} \mathrm{MnO}_{3}$
}

\author{
Brajendra Singh $^{1}\left(\mathbb{D} \cdot\right.$ Priyanka Singh $^{1}(\mathbb{D}$
}

Received: 30 August 2019 / Accepted: 13 February 2020 / Published online: 28 February 2020

(c) Springer Nature Switzerland AG 2020

\begin{abstract}
$\mathrm{Ru}$ doped $\mathrm{Li}_{2} \mathrm{MnO}_{3}$ compositions show the presence of redox couples $\mathrm{Mn}^{+3}-\mathrm{Mn}^{+4}$ and $\mathrm{Ru}^{+4}-\mathrm{Ru}^{+5}$. Due to the presence of these redox couples in $\mathrm{Li}_{2} \mathrm{Mn}_{1-x} \mathrm{Ru}_{\mathrm{x}} \mathrm{O}_{3}(\mathrm{x}=0.05,0.1)$, Ru doped compositions show (i) change in structure (ii) large decrease in impedance $\left(\sim 10^{7}\right.$ to $\sim 10^{5} \mathrm{Ohm}$ ) (iii) degrade methyl orange and methylene blue solution (pH-6) in quick time in presence of tungsten $(\mathrm{W})$ bulb and sun light. Synchrotron X-ray powder diffraction studies show the change in lattice parameters with Ru doping at $\mathrm{Mn}$ site in $\mathrm{Li}_{2} \mathrm{Mn}_{1-\mathrm{x}} \mathrm{Ru}_{\mathrm{x}} \mathrm{O}_{3}(\mathrm{x}=0.05,0.1)$. Raman and Infrared spectroscopic studies show the shift in $\mathrm{Mn}-\mathrm{O}$ stretching mode of $\mathrm{Li}_{2} \mathrm{MnO}_{3}$ towards lower wave number with Ru doping. Soft X-ray absorption spectroscopic studies show the presence of mixed valences of $\mathrm{Mn}^{+3}, \mathrm{Mn}^{+4}, \mathrm{Ru}^{+4}$ and $\mathrm{Ru}^{+5}$ in $\mathrm{Li}_{2} \mathrm{Mn}_{1-\mathrm{x}} \mathrm{Ru}_{\mathrm{x}} \mathrm{O}_{3}(\mathrm{x}=0.05$, 0.1 ) using $L_{2,3}$ and $M_{4}$ edge. UV-Vis diffuse reflectance spectroscopic studies show the optical band gap in visible light range in Ru doped $\mathrm{Li}_{2} \mathrm{Mn}_{1-\mathrm{x}} \mathrm{Ru}_{\mathrm{x}} \mathrm{O}_{3}(\mathrm{x}=0.05,0.1)$ compositions. The presence of $5 \mathrm{mg}$ of $\mathrm{Li}_{2} \mathrm{Mn}_{0.9} \mathrm{Ru}_{0.1} \mathrm{O}_{3}$ degrades $5 \mathrm{ml}$ of methyl orange solution ( $10 \mathrm{mg} / \mathrm{L}$ ) of pH 6 in $5 \mathrm{~min}$ and methylene blue solution (10 mg/L) of pH 6 in $3 \mathrm{~min}$ of exposure in W bulb light.
\end{abstract}

Keywords Synchrotron X-ray ·XAS · Raman · Dye degradation · Optical absorption

\section{Introduction}

Manganese $(\mathrm{Mn})$ containing oxides crystallize in layered, perovskite, spinel, and various other structures, where valence state of $\mathrm{Mn}$ make these oxides vulnerable for various technological applications [1-7]. Colossal magnetoresistance, room temperature magnetism, metal to insulator transition, catalytic and $\mathrm{Li}$ intercalation are some of the properties which are utilized in devices $[1,2,5,6]$. Mixed valence states of $\mathrm{Mn}$ play a major role in altering the properties of the materials as per the technological application need $[2,6,7]$. In perovskite oxides, ratio of $\mathrm{Mn}$ mixed valence $\mathrm{Mn}^{+3} / \mathrm{Mn}^{+4}$ decides the structural, magnetic and transport properties. $\mathrm{Mn}^{+3}$ containing oxides show insulating and antiferromagnetic behaviour while $\mathrm{Mn}^{+4}$ containing oxides also show insulating and antiferromagnetic properties $[2,6]$. When $\mathrm{Mn}^{+3}$ remains present $67 \%$ and $\mathrm{Mn}^{+4} 33 \%$ then perovskite oxides show metallic and ferromagnetic behaviour. Presence of $50 \% \mathrm{Mn}^{+3}$ and $50 \%$ $\mathrm{Mn}^{+4}$ valence states makes spinel oxides susceptible for charging and discharging in Li ion battery $[1,4,7]$.

Hierarchical microstructure of $\mathrm{Mn}_{3} \mathrm{O}_{4}$ has been tried for degradation of methylene blue [8]. $\mathrm{MnO}_{2}$, which has +4 valence state of $\mathrm{Mn}$, has been considered as a photocatalyst and known for its cost effectiveness, adsorption/ oxidizing abilities, large specific surface area and nontoxic nature [9]. It has been observed that some of the good photocatalysts involve metal cations $\mathrm{Fe}^{+2}$ in photo-fanton process for degradation of $\mathrm{MB}$, where redox interaction between $\mathrm{Fe}^{+2}$ and $\mathrm{Fe}^{+3}$ play an important role to produce hydroxyl ions [10]. Ru is a $4 \mathrm{~d}$ transition metal and placed in same group with iron in periodic table. Ru-Mn interaction

Brajendra Singh, brajendr@gmail.com; brajendr@allduniv.ac.in; Priyanka Singh, priyankauoa@gmail.com | ${ }^{1}$ Materials Chemistry Lab, Centre of Material Sciences, University of Allahabad, Allahabad 211002, India. 
induces mixed valence $\mathrm{Ru}^{+4} / \mathrm{Ru}^{+5}$ with $\mathrm{Mn}^{+3} / \mathrm{Mn}^{+4}$ in perovskite oxides and spinel structures [11-14]. When $\mathrm{Ru}^{+4}$ $(0.62 \AA)$ is interact with $\mathrm{Mn}^{+4}(0.53 \AA)$, it undergo redox reaction which leads to $\mathrm{Mn}^{+3}(0.645 \AA)$ and $\mathrm{Ru}^{+5}(0.565 \AA)$ valence states as redox potential of $\mathrm{Ru}^{+4} / \mathrm{Ru}^{+5}(1.07 \mathrm{eV})$ is comparable with that of $\mathrm{Mn}^{+3} / \mathrm{Mn}^{+4}(1.02 \mathrm{eV})$ [15]. $\mathrm{Ru}^{+4} /$ $\mathrm{Ru}^{+5}$ redox couple operates at $4.3 \mathrm{~V}$ vs $\mathrm{Li}$ in the spinel $\mathrm{LiMn}_{2} \mathrm{O}_{4}$ and increases the cycling capacity of $\mathrm{Li}$ ion battery [12]. Ru doping brings cycling stability due to the presence of $\mathrm{Ru}^{+4} / \mathrm{Ru}^{+5}$ redox couple in $\mathrm{Li}_{2} \mathrm{Mn}(\mathrm{Ru}) \mathrm{O}_{3}$ rock salt type layered structure [16-19]. Presence of mixed valence $\mathrm{Ru}^{+4} / \mathrm{Ru}^{+5}$ with $\mathrm{Mn}^{+3} / \mathrm{Mn}^{+4}$ brings long range of magnetic ordering in $\mathrm{La}_{0.7} \mathrm{Ca}_{0.3} \mathrm{Mn}_{1-\mathrm{x}} \mathrm{Ru}_{\mathrm{x}} \mathrm{O}_{3}$ thin films [14]. $\mathrm{Ru}^{+4}$ containing thin film of $\mathrm{La}_{0.7} \mathrm{Ca}_{0.3} \mathrm{Mn}_{0.7} \mathrm{Ru}_{0.3} \mathrm{O}_{3}$ shows colossal magnetoimpedance effects at room temperature [20]. Ru exists in its single valence state $\mathrm{Ru}^{+4}$ in $\mathrm{LaMn}_{1-\mathrm{x}} \mathrm{Ru}_{\mathrm{x}} \mathrm{O}_{3}(\mathrm{x}=0.1,0.2,0.3,0.4)$ compositions and it shows band gad in the range of $\sim 1.27 \mathrm{eV}$ to $1.36 \mathrm{eV}$ [21]. $\mathrm{LaMn}_{1-\mathrm{x}} \mathrm{Ru}_{\mathrm{x}} \mathrm{O}_{3}$ compounds degrade $\mathrm{MO}$ solution $(\mathrm{pH} 2.5)$ and generate photocatalytic oxygen by water in W bulb light [21]. In this study, we have documented the doping effect of $\mathrm{Ru}^{+4}$ at $\mathrm{Mn}^{+4}$ site in $\mathrm{Li}_{2} \mathrm{MnO}_{3}$ on the structure, $\mathrm{Mn}$ and $\mathrm{Ru}$ valence states, and dye degradation properties using methyl orange $(\mathrm{MO})$ and methylene blue $(\mathrm{MB})$ at nominal pH 6.

\section{Experimental}

Polycrystalline $\mathrm{Li}_{2} \mathrm{Mn}_{1-\mathrm{x}} \mathrm{Ru}_{\mathrm{x}} \mathrm{O}_{3}(\mathrm{x}=0.0,0.05,0.1)$ samples were prepared using high temperature solid state reaction route. In the preparation process, we have weighed the stoichiometric amount of high purity LiOH. $\mathrm{H}_{2} \mathrm{O}, \mathrm{MnO}_{2}$ and $\mathrm{RuO}_{2}$. They were thoroughly mixed in an agate mortar and heated at $950^{\circ} \mathrm{C}$ for $12 \mathrm{~h}$ in an ambient atmosphere in muffle furnace. $\mathrm{Sr}_{4} \mathrm{Ru}_{2} \mathrm{O}_{9}$ sample was prepared by taking stoichiometric amount of high purity $\mathrm{SrCO}_{3}$ and $\mathrm{RuO}_{2}$ oxides. The precursors were thoroughly mixed in an agate mortar and calcined at $850^{\circ} \mathrm{C}$ for $36 \mathrm{~h}$ in oxygen atmosphere, and subsequently sintered under oxygen atmosphere at $950^{\circ} \mathrm{C}$ for $36 \mathrm{~h}$ in tubular furnace. $\mathrm{LiMn}_{2} \mathrm{O}_{4}$ sample was prepared by taking stoichiometric amount of high purity $\mathrm{LiOH}_{\mathrm{H}} \mathrm{H}_{2} \mathrm{O}$ and $\mathrm{MnO}_{2}$. The precursors were thoroughly mixed in an agate mortar and heated at $800{ }^{\circ} \mathrm{C}$ for $24 \mathrm{~h}$. $\mathrm{LaMn}_{0.8} \mathrm{Ru}_{0.2} \mathrm{O}_{3}$ sample was prepared by taking stoichiometric amount of high purity $\mathrm{La}_{2} \mathrm{O}_{3}, \mathrm{MnO}_{2}$ and $\mathrm{RuO}_{2}$ oxides. The precursors were thoroughly mixed in an agate mortar and calcined at $900^{\circ} \mathrm{C}$ for $24 \mathrm{~h}$ and subsequently sintered at $1050^{\circ} \mathrm{C}$ for $24 \mathrm{~h}$ in ambient atmosphere. Heating rate was maintained $5^{\circ} \mathrm{C} /$ min during heating and cooling. The $\mathrm{X}$-ray powder diffraction patterns (step size 0.015 , scan speed $1 \mathrm{~s} / \mathrm{step}$ ) using synchrotron radiation $(\lambda=1.09 \AA$ ) were recorded at room temperature at Indian beamline BL-18B, Photon Factory (PF), KEK, Tsukuba, Japan. The incoming $X$-ray beam from the bending magnet of the PF storage ring was collimated with a set of beam-defining slits having vertical opening of $0.2 \mathrm{~mm}$ and $2 \mathrm{~mm}$ in the horizontal direction. The sample was mounted onto an 8-circle goniometer (Huber, Germany) at the focal point of the focusing mirror of the beamline. A slit of $1.5 \mathrm{~mm}$ (horizontal) by $0.25 \mathrm{~mm}$ (vertical) was mounted just before the detector to increase the signal-to-background ratio. Raman spectra of these powder samples were recorded using Renishaw micro-Raman spectrometer (model RM-2000) and focused $\mathrm{Ar}^{+}$laser beam of 514-nm using Leica microscope. The incident laser power was attenuated to $2 \mathrm{~mW}$, and data acquisition time was set to $50 \mathrm{~s}$ for all the samples was used to record the data. The Raman spectra were recorded using Peltier air-cooled CCD detector in the range of $100-3200 \mathrm{~cm}^{-1}$. Fourier transform infrared (FTIR) spectra (absorbance vs. wavenumber) of the samples were recorded using a FTIR Perkin Elmer spectrometer, using the $\mathrm{KBr}$ pellet technique from 400 to $4000 \mathrm{~cm}^{-1}$ at room temperature. Each IR scan recorded after averaging of 25 scans. X-ray absorption spectroscopy (XAS) measurements for $\mathrm{Mn}_{2,3}$, and Ru $\mathrm{M}_{4,5}$ were performed at the Soft $X$-ray absorption spectroscopy (SXAS) beamline (BL-01) of the INDUS 2 synchrotron source source $(2.5 \mathrm{GeV}, 300 \mathrm{~mA})$ at Raja Ramanna Centre for Advanced Technology (RRCAT), Indore, India. This beamline is operating in the energy range 100-1200 eV. Sample pellets were mounted in an ultrahigh vacuum (UHV) chamber with a base pressure of $10^{-10}$ Torr. SXAS data were collected in total electron yield (TEY) mode at room temperature under ultra-high vacuum conditions. Impedance and capacitance measurements were recorded using novacontrol make Impedance analyzer (Alpha-A high performance frequency analyzer) in the frequency range from $1 \mathrm{~Hz}$ to $40 \mathrm{MHz}$ in ambient atmosphere at room temperature. We had used $10.4 \mathrm{~mm}$ diameter and $1.2 \mathrm{~mm}$ thick pellets polished both side with silver paste for these measurements. The wire length was $\sim 2$ feet between the impedance analyzer and sample. The reflectance of the $\mathrm{Li}_{2} \mathrm{Mn}_{1-\mathrm{x}} \mathrm{Ru}_{\mathrm{x}} \mathrm{O}_{3}(\mathrm{x}=0.0,0.05,0.1)$ solid samples were recorded using UV-visible diffuse reflectance spectroscopy (DRS) in a Shimadzu UV-2450 spectrophotometer over a wavelength range of $200-800 \mathrm{~nm} . \mathrm{BaSO}_{4}$ was used as an internal reflectance standard. The absorbance of the Methyl Orange (MO) and Methylene Blue (MB) solution was measured in wavelength range of $200-800 \mathrm{~nm}$ to find out the degradation. To find out the band gap of these samples, the diffuse reflectance data were converted to the Kubelka-Munk function by equation [22]:

$F(R)=(1-R)^{2} / 2 R$ 
where $R$ is reflectance, $F(R)$ is proportional to extinction coefficient $a$.

Band gaps were determined by Tauc plots using equation [23]:

$[\alpha \mathrm{h} v]^{1 / \mathrm{n}}=\mathrm{A}\left[\mathrm{h} v-\mathrm{E}_{\mathrm{g}}\right]$

where $\mathrm{u}$ is frequency, $\mathrm{A}$ is absorption constant, $\mathrm{h}$ is Planck constant and $E_{g}$ is band gap. Here, $n$ denotes the nature of band gap. For indirect band gap $\mathrm{n}=2$ and direct band gap $n=1 / 2$ is used.

To understand the dye degradation ability of $\mathrm{Li}_{2} \mathrm{Mn}_{1-\mathrm{x}} \mathrm{Ru}_{\mathrm{x}} \mathrm{O}_{3}(\mathrm{x}=0.0$ and 0.1$)$, we have selected methyl orange (MO) and methylene blue (MB) dyes for degradation. $\mathrm{MnO}_{2}$ has been used as reference for $\mathrm{MO}$ and $\mathrm{MB}$ degradation. The photocatalytic degradation of aqueous methyl orange and methylene blue dyes by $\mathrm{Li}_{2} \mathrm{Mn}_{1-\mathrm{x}} \mathrm{Ru}_{\mathrm{x}} \mathrm{O}_{3}$, and $\mathrm{MnO}_{2}$, was carried out in a borosil make glass sample vials. Sample vial further placed in ultrasonicator and exposed in visible light of 200 Watt incandescent tungsten (W) bulb (300 to $900 \mathrm{~nm}$ ) under constant flow of water (to maintain the constant temperature). $\mathrm{MO}$ and $\mathrm{MB}$ stock solutions of $10 \mathrm{mg} / \mathrm{L}$ concentration were prepared in ultra pure water. Hydrochloric acid was used to maintain $\mathrm{pH}$ of dye solutions. For dye degradation experiment, we have used $5 \mathrm{mg}$ of catalyst in $5 \mathrm{ml}$ dye solutions of $10 \mathrm{mg} / \mathrm{L}$ concentration for all the compositions. Before mixing catalysts in dye solutions, the $\mathrm{pH}$ of dye solutions was maintained 6 . Ultrasonicator was used for proper mixing of catalyst and dye solution during exposing the mixture in visible light. The distance between $200 \mathrm{~W}$ incandescent tungsten(W) bulb and sample vial was maintained $15 \mathrm{~cm}$. Visible part of sample vials $(4 \mathrm{~cm}$ length and $1.6 \mathrm{~cm}$ diameter) was effectively exposed to $70.77 \mathrm{~mW} / \mathrm{cm}^{2}$ power of radiation. The samples were filtered using whatmann filter paper after exposing in $\mathrm{W}$ bulb light and absorbance of dye solutions were recorded in a Shimadzo make UV-Visible spectrometer over a wavelength range of $200-800 \mathrm{~nm}$. The concentration of $M B$ were calculated as $C_{t}=C_{0}\left(A_{t} / A_{0}\right)$, where $C_{0}$ - initial $M B$ concentration, $A_{0}$-initial absorbance (at $\lambda=662 \mathrm{~nm}$ ), $C_{t}-M B$ concentration at time $t$, and $A_{t}$-absorbance (at maxima of peak on $t$ minute), respectively.The degradation rate $\%$ was calculated by $\left[\left(A_{0}-A_{t}\right) /\right.$ $\left.\mathrm{A}_{0}\right] \times 100$.

\section{Results and discussion}

$\mathrm{Li}_{2} \mathrm{MnO}_{3}$ crystallizes in monoclinic unit cell and space group C2/m (Fig. 1). It is a layered structure, where a layer of $\mathrm{Li}$ ions, and a mixed layer of $\mathrm{Li}$ and $2 \mathrm{Mn}$ ions are alternating between closed packed oxygen layers. In a crystal, Li ions occupy three positions ( $2 \mathrm{~b}, 2 \mathrm{c}$ and $4 \mathrm{~h}$ ), oxygen ions occupy two positions ( $4 \mathrm{i}$ and $8 \mathrm{j}$ ) and $\mathrm{Mn}$ atom occupies one position (4g) $[24,25]$. In $\mathrm{MnO}_{6}$ octahedra, two types of $\mathrm{Mn}-\mathrm{O}$ bonds of $1.90 \AA \AA$ and $1.91 \AA$ A exists $[24,25]$.

Figure 2 shows the synchrotron $\mathrm{X}$-ray powder diffraction patterns of $\mathrm{Li}_{2} \mathrm{Mn}_{1-\mathrm{x}} \mathrm{Ru}_{\mathrm{x}} \mathrm{O}_{3}[\mathrm{x}=0.0,0.05,0.1]$ compositions from 10 degree to 70 degree. We have found stoichiometric single phase for $\mathrm{Li}_{2} \mathrm{Mn}_{1-\mathrm{x}} \mathrm{Ru}_{\mathrm{x}} \mathrm{O}_{3}[\mathrm{x}=0.0,0.05$, $0.1]$ compositions and diffraction patterns matches with the reference code ICSD-202639 and JCPDS-01-084-1634 patterns. All the peaks are matching with the reported results in literature. Parent and Ru doped diffraction patterns show the characteristic peaks (020), (110), (021) and (110) which confirms the crystallization of these compositions in C2/m. Figure 3 shows the close look of the peaks of normalized intensity for all the compositions. It has been observed that the peaks (001), (020), (110), (130) shifts at lower theta with the increase in Ru concentration. Shifting of peaks shows the expansion of unit cell with $\mathrm{Ru}$ substitution due to the higher ionic size of $\mathrm{Ru}^{+4}(0.76 \AA)$

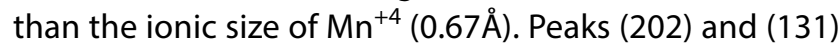
merge together with Ru substitution at Mn site. Peak ( $\overline{3}$ 31) shifted towards lower theta value for $R u=0.05$ composition but for Ru-0.1 composition ( $\overline{3} 31)$ peak split into (331) and (060). Crystallite size for all the composition has been calculated using Debye Sherrer formula (Crystallite
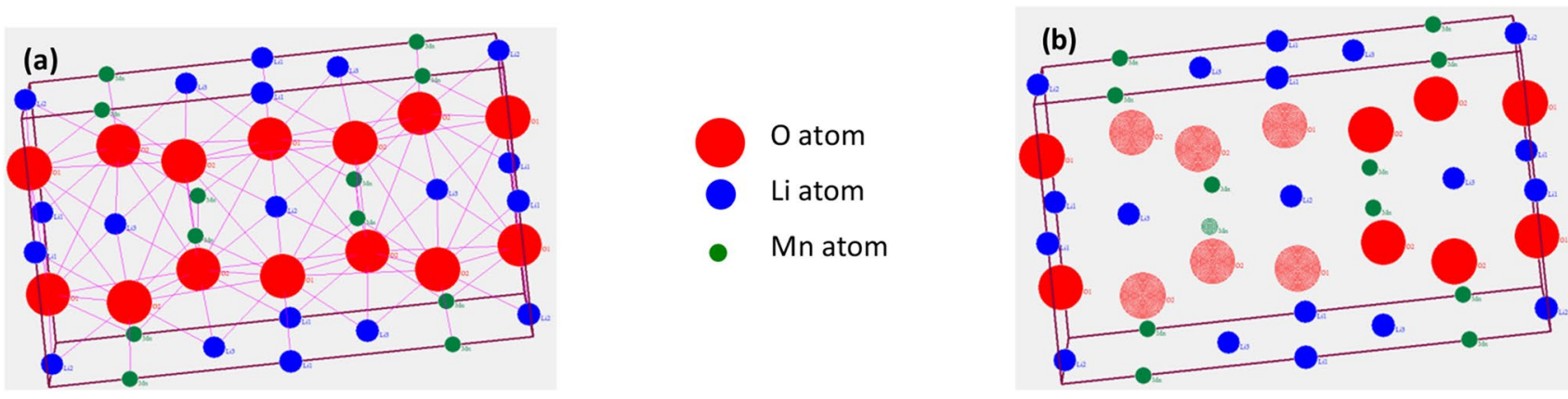

Fig. 1 a Crystal structure of monoclinic $\mathrm{Li}_{2} \mathrm{MnO}_{3}$. b Shaded atoms (six $\mathrm{O}$ and one $\mathrm{Mn}$ atoms) show the configuration of $\mathrm{Mn}-\mathrm{O}_{6}$ octahedra in $\mathrm{Li}_{2} \mathrm{MnO}_{3}$ 


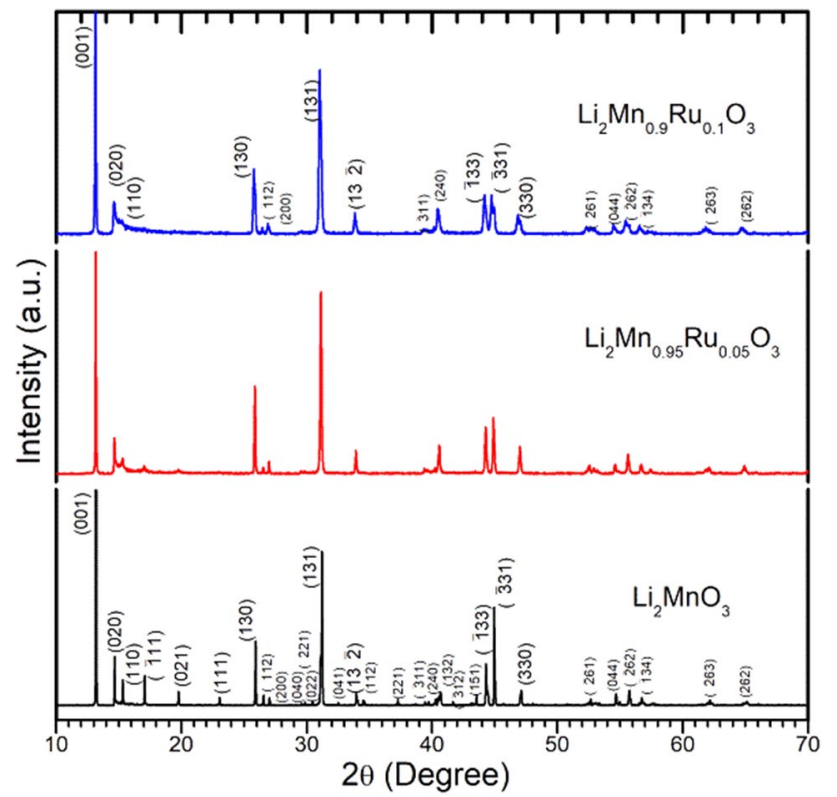

Fig. 2 Synchrotron $X$-ray powder diffraction patterns of $\mathrm{Li}_{2} \mathrm{Mn}_{1-\mathrm{x}} \mathrm{Ru}_{\mathrm{x}} \mathrm{O}_{3}(\mathrm{x}=0.0,0.05,0.1)$. Ru doped compositions show the single phase as $\mathrm{Li}_{2} \mathrm{MnO}_{3}$. Peaks are indexed for $\mathrm{Li}_{2} \mathrm{MnO}_{3}$

size $(\AA)=0.9 \lambda / d \cos \theta)$. Ru doping decreases crystallite size of materials. Table 1 summarizes the results of the analysis of synchrotron X-ray powder diffraction patterns. These results show that $\mathrm{Ru}$ has been successfully doped at $\mathrm{Mn}$ site in $\mathrm{Li}_{2} \mathrm{Mn}_{1-\mathrm{x}} \mathrm{Ru}_{\mathrm{x}} \mathrm{O}_{3}[\mathrm{x}=0.05,0.1]$. To explore the shifting of peaks at lower theta value and lowering of crystallite size at micro level by Ru doping at Mn site, we have recorded the Raman spectra of these compositions [12, 26].

Figure 4 shows the Raman peaks for powder samples of $\mathrm{Li}_{2} \mathrm{Mn}_{1-\mathrm{x}} \mathrm{Ru}_{\mathrm{x}} \mathrm{O}_{3}[\mathrm{x}=0.0,0.05,0.1]$ compositions. Theoretical calculations predict the 15 Raman active optical modes, in which 7 modes are $A_{g}$ and 8 modes are $B_{g}$ [27]. In monoclinic space group $\mathrm{C} 2 / \mathrm{m}, A_{g}$ modes are generated from the symmetric vibrations of cations along $b$-axis. $B_{g}$ modes are generated from the symmetric vibrations of cations along $\mathrm{a}$ and c-axis. The vibrations of octahedrally coordinated $\mathrm{Mn}$ atom at $4 \mathrm{~g}$ position results $1 \mathrm{~A}_{\mathrm{g}}$ and $2 \mathrm{~B}_{\mathrm{g}}$ modes, while $1 \mathrm{~A}_{\mathrm{g}}$ and $2 \mathrm{~B}_{\mathrm{g}}$ modes are due to $\mathrm{Li}$ atom at $4 \mathrm{~h}$ site. $O$ atom at $4 \mathrm{i}$ position generates $2 \mathrm{~A}_{g}$ and $1 \mathrm{~B}_{g}$ modes, and remaining $3 \mathrm{~A}_{g}$ and $3 B_{g}$ modes can be assigned to vibrations of $O$ atom at $8 j$ site $[28,29]$. We have clearly observed 14 active Raman modes in our synthesized $\mathrm{Li}_{2} \mathrm{Mn}_{1-\mathrm{x}} \mathrm{Ru}_{\mathrm{x}} \mathrm{O}_{3}$ samples while other groups have reported only 8 Raman peaks in monoclinic $\mathrm{Li}_{2} \mathrm{MnO}_{3}$ samples $[28,29]$. The observed Raman Peaks positions are summarized in Table 2 for $\mathrm{Li}_{2} \mathrm{Mn}_{1-\mathrm{x}} \mathrm{Ru}_{\mathrm{x}} \mathrm{O}_{3}$ $[x=0.0,0.05,0.1]$ compositions. Ru substitution at $\mathrm{Mn}$ site shifts $A_{g}$ peak at $\sim 615 \mathrm{~cm}^{-1}$ of $\mathrm{Li}_{2} \mathrm{MnO}_{3}$ to lower value $\sim 610.8 \mathrm{~cm}^{-1}$ for $\mathrm{x}=0.05$ composition. This observation is similar to the $\mathrm{Ru}$ doped $\mathrm{LiMn}_{2} \mathrm{O}_{4}$ samples where we had observed the peak shifting towards lower wave numbers [12]. Ru as a $4 \mathrm{~d}$ transition metal having extended orbitals and higher spin orbit coupling constant $800 \mathrm{~cm}^{-1}$ in comparison with $100 \mathrm{~cm}^{-1}$ of $\mathrm{Mn}$. It makes Ru-O bond stronger than $\mathrm{Mn}-\mathrm{O}$ bond which reflect in shifting of $\mathrm{A}_{\mathrm{g}}$ vibrational peak towards lower wave numbers.

For $\mathrm{Ru}=0.1$ composition, we have observed that Raman peaks splitted into multiple peaks for stretching modes of $\mathrm{Mn}-\mathrm{O}$ vibrations, it shows that the multiple cations vibration contributing to stretching modes. Figure 5 shows the Infra red (IR) peaks for powder samples of $\mathrm{Li}_{2} \mathrm{Mn}_{1-\mathrm{x}} \mathrm{Ru}_{\mathrm{x}} \mathrm{O}_{3}$ $[x=0.0,0.1]$ compositions. Theoretical calculations predict the $7 A_{u}$ and $11 B_{u}$ IR active optical modes [27]. We have found 7 peaks for $\mathrm{Li}_{2} \mathrm{MnO}_{3}$ which are similar with the reported experimental studies in literature [30]. In $\mathrm{Li}_{2} \mathrm{Mn}_{0.9} \mathrm{Ru}_{0.1} \mathrm{O}_{3}$, some Raman peaks merge and total 5 peaks have been observed. All the peaks have been sihifted towards lower wavenumber with the doping of $\mathrm{Ru}$ at $\mathrm{Mn}$ site. Presence of multiple peaks and shift of other vibrational peaks in Raman and IR spectra motivated us to find the valence states of transition metals $\mathrm{Mn}$ and $\mathrm{Ru}$ in $\mathrm{Li}_{2} \mathrm{Mn}_{1-\mathrm{x}} \mathrm{Ru}_{\mathrm{x}} \mathrm{O}_{3}[\mathrm{x}=0.05,0.1]$ compositions.

In Figure 6a, we show $\mathrm{Mn}-\mathrm{L}_{2,3}$ absorption edge spectra of $\mathrm{Li}_{2} \mathrm{Mn}_{1-\mathrm{x}} \mathrm{Ru}_{\mathrm{x}} \mathrm{O}_{3}[\mathrm{x}=0.0,0.05,0.1]$ and $\mathrm{Li}_{2} \mathrm{Mn}_{2} \mathrm{O}_{4}$ systems together with that of $\mathrm{Mn}_{2} \mathrm{O}_{3}, \mathrm{MnO}_{2}$ (where $\mathrm{Mn}$ exist in +3 and +4 valence states) for comparison. The $L_{2}$ edge and $L_{3}$ edge correspond to the $2 p_{1 / 2}-3 d\left(t_{2 g}\right.$ and $e_{g}$ orbitals) and $2 p_{3 / 2}-3 d\left(t_{2 g}\right.$ and $e_{g}$ orbitals) transitions, respectively. Cathode material $\mathrm{LiMn}_{2} \mathrm{O}_{4}$ is known for showing $50-50 \%$ of $\mathrm{Mn}^{+3}$ and $\mathrm{Mn}^{+4}$ valence states [12]. In $\mathrm{L}_{3}$ absorption edge, We have observed two peaks at $642.30 \mathrm{eV}$ and $643.39 \mathrm{eV}$ in $\mathrm{LiMn}_{2} \mathrm{O}_{4}$ which are identical to peaks at 642.37 in $\mathrm{Mn}_{2} \mathrm{O}_{3}$ and $643.45 \mathrm{eV}$ in $\mathrm{MnO}_{2}$ [31]. It shows the presence of $\mathrm{Mn}^{+3}$ and $\mathrm{Mn}^{+4}$ valence states in $\mathrm{Li}_{2} \mathrm{Mn}_{2} \mathrm{O}_{4}$ [31] . In $\mathrm{Li}_{2} \mathrm{MnO}_{3}(\mathrm{x}=0.0)$, we have found peak at $643.45 \mathrm{eV}$ which is comparable to peak observed in $\mathrm{MnO}_{2}$, it shows the presence of $\mathrm{Mn}^{+4}$ valence state in $\mathrm{Li}_{2} \mathrm{MnO}_{3}$. Figure $6 \mathrm{~b}$ shows the close look of $\mathrm{L}_{3}$ edge for $\mathrm{Li}_{2} \mathrm{Mn}_{1-\mathrm{x}} \mathrm{Ru}_{\mathrm{x}} \mathrm{O}_{3}[\mathrm{x}=0.0$, 0.05, 0.1]. In $\mathrm{Li}_{2} \mathrm{Mn}_{0.95} \mathrm{Ru}_{0.05} \mathrm{O}_{3}(\mathrm{x}=0.05)$, we have observed peaks at $643.35 \mathrm{eV}$ and in $\mathrm{Li}_{2} \mathrm{Mn}_{0.9} \mathrm{Ru}_{0.1} \mathrm{O}_{3}(\mathrm{x}=0.1)$ we have found peaks at $643.25 \mathrm{eV}$. These peaks are shifting towards lower energy as Ru concentration is increasing. It confirms the presence of $\mathrm{Mn}^{+3}$ valence state along with $\mathrm{Mn}^{+4}$ in $\mathrm{Li}_{2} \mathrm{Mn}_{0.95} \mathrm{Ru}_{0.05} \mathrm{O}_{3}$ and $\mathrm{Li}_{2} \mathrm{Mn}_{0.9} \mathrm{Ru}_{0.1} \mathrm{O}_{3}$.

In Figure $7 \mathrm{a}$, we show $\mathrm{Ru}-\mathrm{M}_{4}$ absorption edge spectra of $\mathrm{Li}_{2} \mathrm{Mn}_{1-\mathrm{x}} \mathrm{Ru}_{\mathrm{x}} \mathrm{O}_{3}[\mathrm{x}=0.05,0.1]$ and $\mathrm{LaMn}_{0.8} \mathrm{Ru}_{0.2} \mathrm{O}_{3}$ systems together with that of $\mathrm{RuO}_{2}$ and $\mathrm{Sr}_{4} \mathrm{Ru}_{2} \mathrm{O}_{9}$, where $\mathrm{Ru}$ exist in +4 and +5 valence states $[11,15,32,33]$. The $M_{4}$ 

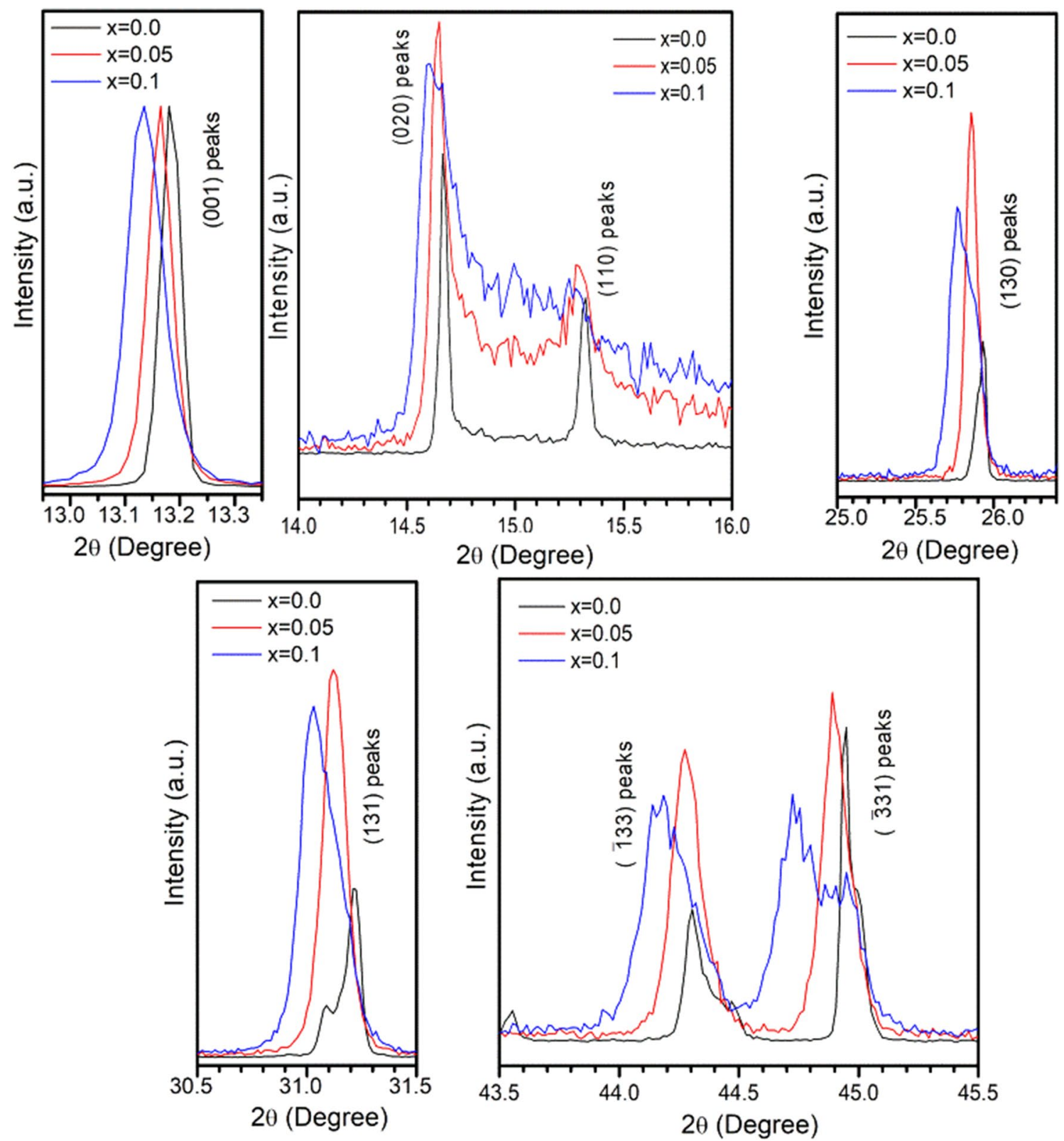

Fig. 3 Zoomed peaks of synchrotron X-ray powder diffraction patterns of $\mathrm{Li}_{2} \mathrm{Mn}_{1-x} \mathrm{Ru}_{\mathrm{x}} \mathrm{O}_{3}(\mathrm{x}=0.0,0.05,0.1)$. Shifting of peaks towards lower theta value shows the expansion of lattice with Ru substitution at $\mathrm{Mn}$ in $\mathrm{Li}_{2} \mathrm{MnO}_{3}$

edge and $\mathrm{M}_{5}$ edge correspond to the electronic transition from Ru-3d $d_{5 / 2}$ to Ru p orbitals and Ru-3d $d_{3 / 2}$ to Ru p orbitals respectively. The $\mathrm{M}_{4}$ edge of $\mathrm{RuO}_{2}$ has been found at $287.95 \mathrm{eV}$ which is similar with the reported by zhou et al. [33]. Zhou et al. have found $\mathrm{M}_{4}$ edge of $\mathrm{Ru}$ at $288 \mathrm{eV}$ in $\mathrm{RuO}_{2}$ nano particles [33]. The $\mathrm{M}_{4}$ absorption edge has been found at $289.74 \mathrm{eV}$ for $\mathrm{Sr}_{4} \mathrm{Ru}_{2} \mathrm{O}_{9}$, which is $1.78 \mathrm{eV}$ more than $\mathrm{M}_{4}$ edge peak of $\mathrm{RuO}_{2}$. This result shows the presence of +5 valence state of $\mathrm{Ru}$ in $\mathrm{Sr}_{4} \mathrm{Ru}_{2} \mathrm{O}_{9}$. These results are similar with findings of Hu et al. [32] where they have shown that $\mathrm{Ru}$ remains in +4 and +5 valence states for $\mathrm{RuO}_{2}$ and $\mathrm{Sr}_{4} \mathrm{Ru}_{2} \mathrm{O}_{9}$ respectively $[32,34]$. In our observation, $\mathrm{LaMn}_{0.8} \mathrm{Ru}_{0.2} \mathrm{O}_{3}$ has been found showing $\mathrm{M}_{4}$ absorption peak of Ru at $288.05 \mathrm{eV}$ which is very close to the absorption peak (at $287.95 \mathrm{eV}$ ) of $\mathrm{RuO}_{2}$ [33]. This result is very much similar with the reported result by patra et al., where it has been found that $\mathrm{Ru}$ remains in +4 valence state in $\mathrm{LaMn}_{0.8} \mathrm{Ru}_{0.2} \mathrm{O}_{3}$ [21]. In $\mathrm{Li}_{2} \mathrm{Mn}_{0.95} \mathrm{Ru}_{0.05} \mathrm{O}_{3}(\mathrm{x}=0.05)$, we have 
Table 1 Synchrotron $\mathrm{X}$-ray powder diffraction data acquisition conditions and lattice parameters of $\mathrm{Li}_{2} \mathrm{Mn}_{1-\mathrm{x}} \mathrm{Ru}_{\mathrm{x}} \mathrm{O}_{3}$

\begin{tabular}{llll}
\hline & $\mathrm{Li}_{2} \mathrm{MnO}_{3}$ & $\begin{array}{l}\mathrm{Li}_{2} \mathrm{Mn}_{0.95} \\
\mathrm{Ru}_{0.05} \mathrm{O}_{3}\end{array}$ & $\begin{array}{l}\mathrm{Li}_{2} \mathrm{Mn}_{0.9} \\
\mathrm{Ru}_{0.1} \mathrm{O}_{3}\end{array}$ \\
\hline Space group & $\mathrm{C} 2 / \mathrm{m}$ & $\mathrm{C} 2 / \mathrm{m}$ & $\mathrm{C} 2 / \mathrm{m}$ \\
$\mathrm{a}(\AA)$ & 4.938 & 4.944 & 4.946 \\
$\mathrm{~b}(\AA)$ & 8.542 & 8.561 & 8.592 \\
$\mathrm{C}(\AA)$ & 5.032 & 5.037 & 5.048 \\
$\beta$ (deg) & 109.34 & 109.30 & 109.43 \\
Angle range & 10 to 70 & 10 to 70 & 10 to 70 \\
Step size (deg) & 0.015 & 0.015 & 0.015 \\
X-ray wavelength $(\lambda)$ & $1.09 \AA$ & $1.09 \AA$ & $1.09 \AA$ \\
Crystallite size $(\mathrm{nm})$ & 135.29 & 107.34 & 74.25 \\
\hline
\end{tabular}

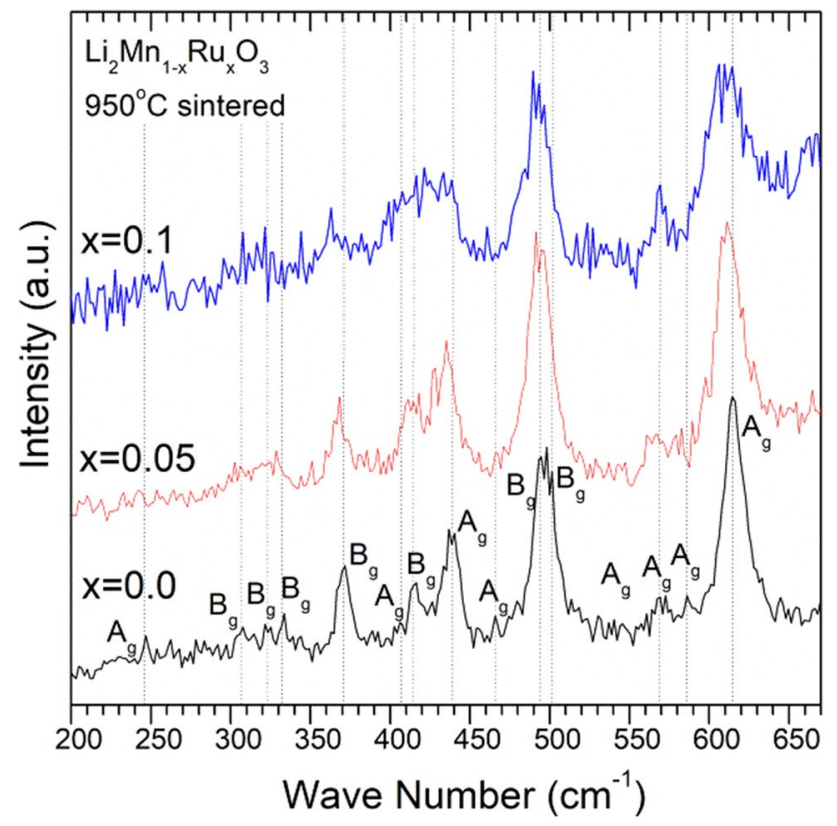

Fig. 4 Raman shift for powder samples of $\mathrm{Li}_{2} \mathrm{Mn}_{1-x} \mathrm{Ru}_{\mathrm{x}} \mathrm{O}_{3} \quad(x=0.0$, $0.05,0.1)$. Vertical lines show the peak positions for $\mathrm{Li}_{2} \mathrm{MnO}_{3}$

Table 2 Frequencies of experimentally observed Raman active modes of $\mathrm{Li}_{2} \mathrm{Mn}_{1-\mathrm{x}} \mathrm{Ru}_{\mathrm{x}} \mathrm{O}_{3}$

\begin{tabular}{lllll}
\hline Symmetry & $\begin{array}{l}\text { Frequency } \\
\left(\mathrm{cm}^{-1}\right) \text { theory }\end{array}$ & \multicolumn{3}{l}{ Frequency $\left(\mathrm{cm}^{-1}\right)$ experiment } \\
\cline { 3 - 5 } & {$[28,29]$} & $\mathrm{x}=0.0$ & $\mathrm{x}=0.05$ & $\mathrm{x}=0.1$ \\
\hline $\mathrm{A}_{\mathrm{g}}$ & 621.41 & 614.7 & 610.8 & $609.3,597.7$ \\
& 577.03 & 569.06 & 565.2 & 568.05 \\
& 448.43 & 439.25 & $435.4,426.9$ & $433.1,421.2$ \\
$\mathrm{~B}_{2 \mathrm{~g}}$ & 498.39 & 501.8 & 495.7 & 494.19 \\
& 496.74 & 494.2 & 491.4 & 484.5 \\
& 425.98 & 413.6 & 412.7 & Multiple peaks \\
& 376.98 & 370.9 & 368.2 & 362.5 \\
\hline
\end{tabular}

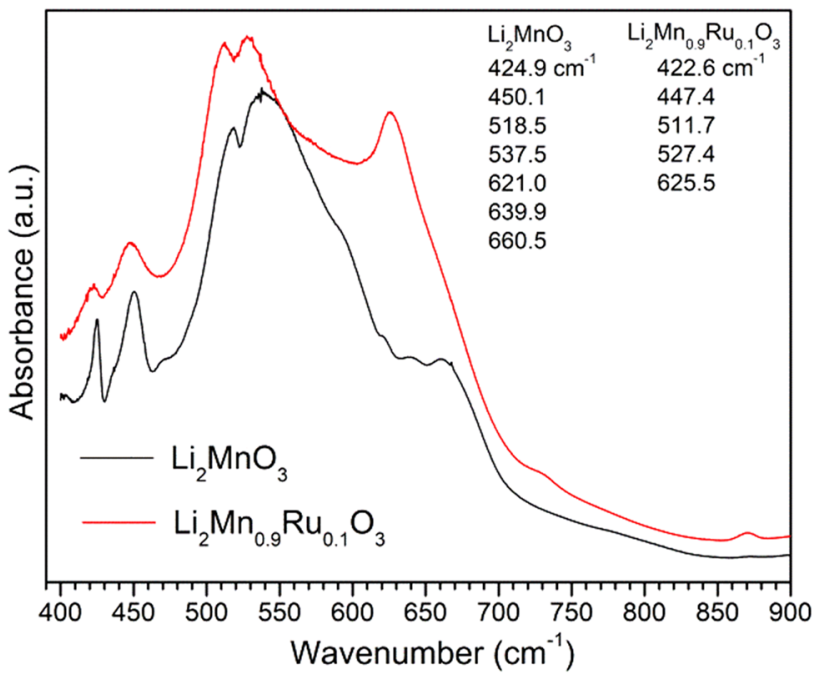

Fig. 5 Peaks of Infrared spectra for powder samples of $\mathrm{Li}_{2} \mathrm{Mn}_{1-\mathrm{x}} \mathrm{Ru}_{\mathrm{x}} \mathrm{O}_{3}(\mathrm{x}=0.0,0.1)$

observed multiple peaks at 288.15 and $289.88 \mathrm{eV}$ and similarly in $(x=0.1)$ two peaks at 288.02 and $289.88 \mathrm{eV}$ have been observed. These two absorption peaks are similar with the $\mathrm{M}_{4}$ absorption peak of $\mathrm{RuO}_{2}$ and $\mathrm{Sr}_{4} \mathrm{Ru}_{2} \mathrm{O}_{9}$. These results show that $\mathrm{Li}_{2} \mathrm{Mn}_{0.9} \mathrm{Ru}_{0.1} \mathrm{O}_{3}$ and $\mathrm{Li}_{2} \mathrm{Mn}_{0.95} \mathrm{Ru}_{0.05} \mathrm{O}_{3}$ contain multi valence states of $\mathrm{Ru}\left(\mathrm{Ru}^{+4}\right.$ and $\left.\mathrm{Ru}^{+5}\right)$. Fitting of $\mathrm{M}_{4}$ absorption peak of Ru shows the \% amount of $\mathrm{Ru}$ valence state in $\mathrm{Li}_{2} \mathrm{Mn}_{0.9} \mathrm{Ru}_{0.1} \mathrm{O}_{3}$ and $\mathrm{Li}_{2} \mathrm{Mn}_{0.95} \mathrm{Ru}_{0.05} \mathrm{O}_{3}$ (Fig. 7b). $\mathrm{Li}_{2} \mathrm{Mn}_{0.95} \mathrm{Ru}_{0.05} \mathrm{O}_{3}$ compound contains $48 \% \mathrm{Ru}^{+4}$ valence state and $52 \% \mathrm{Ru}^{+5}$ valence state. $\mathrm{Li}_{2} \mathrm{Mn}_{0.9} \mathrm{Ru}_{0.1} \mathrm{O}_{3}$ compound contains $32 \% \mathrm{Ru}^{+4}$ valence state and $68 \% \mathrm{Ru}^{+5}$ valence state.

To see the effect of multivalence states of $\mathrm{Ru}$ and $\mathrm{Mn}$ in $\mathrm{Li}_{2} \mathrm{Mn}_{1-\mathrm{x}} \mathrm{Ru}_{\mathrm{x}} \mathrm{O}_{3}[\mathrm{x}=0.05,0.1]$ on the transport properties of $\mathrm{Li}_{2} \mathrm{MnO}_{3}$, we have measured the frequency dependent impedance measurements. Figure 8 shows the impedance and capacitance for these compositions in the frequency range $10^{3}$ to $4 \times 10^{7} \mathrm{~cm}^{-1}$. At frequency $10^{3}$ Hertz, $x=0.0$ composition show $1.38 \times 10^{7} \mathrm{Ohm}$ impedance while $x=0.05$ and 0.1 show $2.82 \times 10^{5}$ and $5.37 \times 10^{4}$ Ohm respectively. Capacitance is found $1.05 \times 10^{-11} \mathrm{~F}$ at frequency $10^{3}$ Hertz for $x=0.0$ composition while $x=0.05$ and 0.1 compositions show $5.15 \times 10^{-10} \mathrm{~F}$ and $2.71 \times 10^{-9}$ $F$ respectively. These measurements show the decrease in impedance and increase in capacitance with the substitution of $\mathrm{Ru}$ in $\mathrm{Li}_{2} \mathrm{MnO}_{3}$. On increasing frequency, impedance further decreases for all the compositions. These observations confirm the presence of $\mathrm{Mn}^{+3}$ valence state along with $\mathrm{Mn}^{+4}$ valence state in Ru doped compositions. While synthesis of $\mathrm{Li}_{2} \mathrm{Mn}_{1-\mathrm{x}} \mathrm{Ru}_{\mathrm{x}} \mathrm{O}_{3}[\mathrm{x}=0.0,0.05,0.1]$ compositions, we have observed that parent $x=0.0$ composition is in reddish colour and Ru doped compositions $x=0.05$ and 0.1 are in black colour. To find out the absorption capability in 

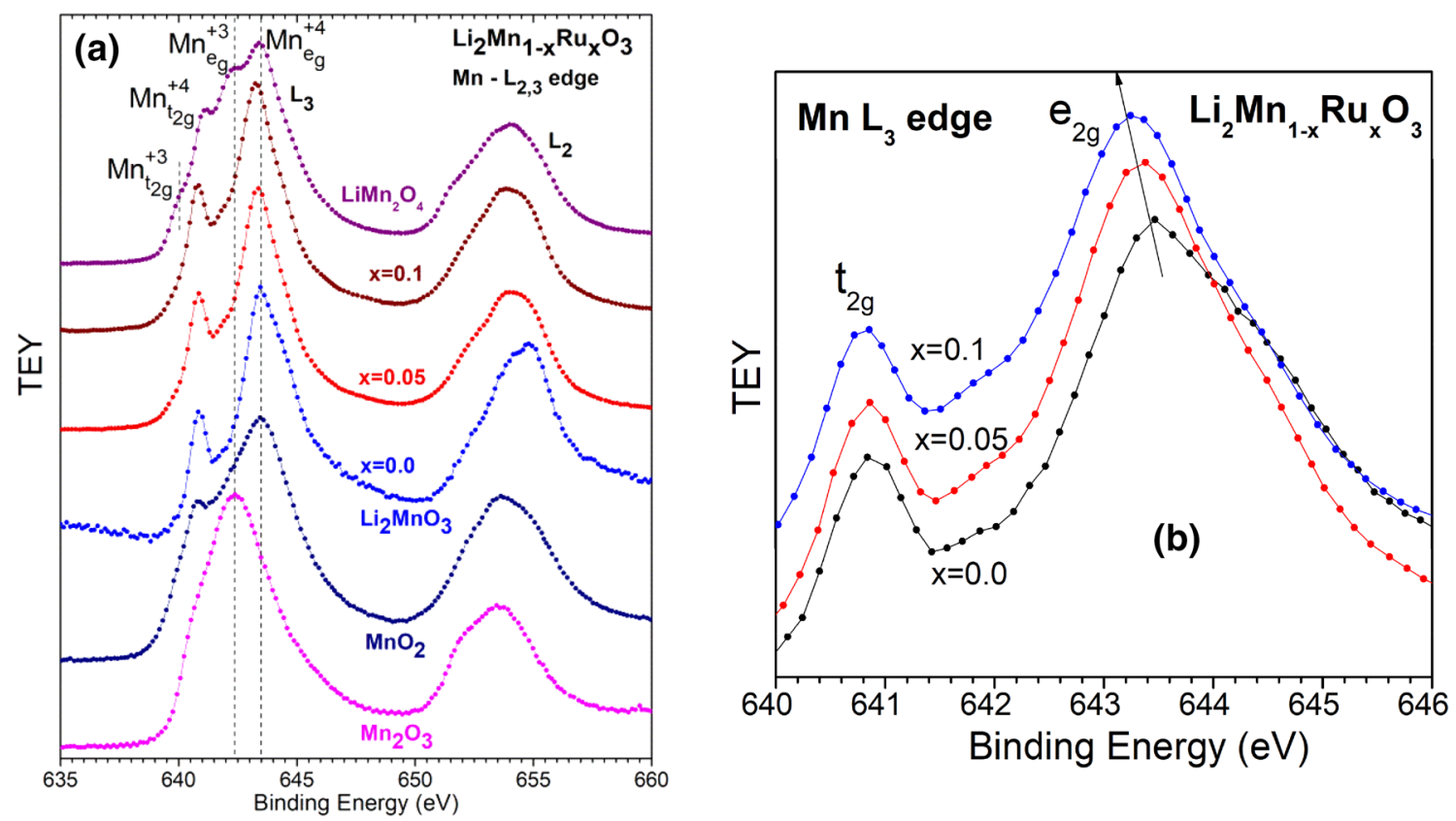

Fig. 6 a XAS spectra of $\mathrm{L}_{2,3}$ edge for $\mathrm{Li}_{2} \mathrm{Mn}_{1-\mathrm{x}} \mathrm{Ru}_{\mathrm{x}} \mathrm{O}_{3}[\mathrm{x}=0.0,0.05,0.1]$ and $\mathrm{LiMn}_{2} \mathrm{O}_{4}$. XAS spectra of $\mathrm{MnO}_{2}$ and $\mathrm{Mn}_{2} \mathrm{O}_{3}$ used for reference of $\mathrm{Mn}^{+3}$ and $\mathrm{Mn}^{+4}$ valence states peaks. $\mathbf{b} \mathrm{L}_{3}$ edge of Ru doped $\mathrm{Li}_{2} \mathrm{MnO}_{3}$ compositions, which show shift in Mn peaks with Ru substitution

visible light, we have measured UV-vis diffuse reflectance spectroscopic measurements.

Figure 9 shows the reflectance of the $\mathrm{Li}_{2} \mathrm{Mn}_{1-\mathrm{x}} \mathrm{Ru}_{\mathrm{x}} \mathrm{O}_{3}$ $[x=0.0,0.05,0.1]$ compositions. $\mathrm{TiO}_{2}$ (commercial sample) is used as reference for reflectance. Optical reflectance spectra of $\mathrm{Li}_{2} \mathrm{MnO}_{3}$ showed a sharp edge at 610 to $750 \mathrm{~nm}$, which is similar with the reported by Tamilarasan et al. [35]. The peaks $\sim 610 \mathrm{~nm}$ corresponds to a HOMO-LUMO gap between filled $\mathrm{O}(2 \mathrm{p})$ states and empty $\mathrm{Mn}(\mathrm{IV})(3 \mathrm{~d}-4 \mathrm{~s}$ ) states. Figure 10 shows the band gap of the $\mathrm{Li}_{2} \mathrm{Mn}_{1-\mathrm{x}} \mathrm{Ru}_{\mathrm{x}} \mathrm{O}_{3}$ $[x=0.0,0.05,0.1]$ compositions, which was calculated using Kubelka-Munk function and Tauc plot [22, 23]. Tauc plot gave an energy band gap $2.17 \mathrm{eV}$ for parent $\mathrm{Li}_{2} \mathrm{MnO}_{3}$ which is in agreement with the theoretical estimations $[35,36]$. In Ru doped compositions, we have observed some more reflectance peaks near to $480 \mathrm{~nm}$ and $577 \mathrm{~nm}$. Band gap calculation suggests the presence of multiple absorption of band gap 1.97, 2.15, 2.33 and $2.41 \mathrm{eV}$ for $\mathrm{x}=0.1$ composition and band gap 1.91, 2.09 and $2.24 \mathrm{eV}$ for $x=0.05$ composition. These experimental determined optical band gaps are reported by theoretical studies on the systems which have Mn mixed valences.

The optical absorption in Mn containing systems is controlled by electric dipole matrix elements that preserve spins of electrons. Features observed in optical conductivity close to $1 \mathrm{eV}, 3 \mathrm{eV}$ have been ascribed due to the $\mathrm{d}-\mathrm{d}$ charge transfer between $M n$ ions on different sites, $e_{g}-e_{g}$ transitions in perovskite manganite systems [37-39]. These band gap values $1.91,2.09$ and $2.24 \mathrm{eV}$ for $\mathrm{x}=0.05$ composition and band gap 1.97, 2.15, 2.33 and $2.41 \mathrm{eV}$ for $\mathrm{x}=0.1$ composition suggest the optical activity of $\mathrm{Li}_{2} \mathrm{Mn}_{1-x} \mathrm{Ru}_{\mathrm{x}} \mathrm{O}_{3}$ $[x=0.05,0.1]$ compositions in visible light.

Ranjeh et al. have investigated photocatalytic properties of $\mathrm{Li}_{2} \mathrm{MnO}_{3}$ bulk and nano particles using aqueous solution via visible light for degradation of dyes acid red88 and malachite green [40]. Acid red dye degradation was found $17.6 \%$ by bulk $\mathrm{Li}_{2} \mathrm{MnO}_{3}$ and $40.9 \%$ by nano $\mathrm{Li}_{2} \mathrm{MnO}_{3}$. They have shown following mechanism of degradation using $\mathrm{Li}_{2} \mathrm{MnO}_{3}$ : [40]

$$
\begin{aligned}
& \mathrm{Li}_{2} \mathrm{MnO}_{3}+\mathrm{h} v \rightarrow\left(\mathrm{Li}_{2} \mathrm{MnO}_{3}\right) *+\mathrm{e}^{-}+\mathrm{h}^{+} \\
& \mathrm{O}_{2}+\mathrm{e}^{-} \rightarrow \mathrm{O}_{2}^{-} \\
& \mathrm{O}_{2}^{-}+2 \mathrm{H}^{+} \rightarrow \mathrm{H}_{2} \mathrm{O}_{2} \\
& \mathrm{OH}^{-}+\mathrm{h}^{+} \rightarrow \mathrm{OH} \\
& \mathrm{H}_{2} \mathrm{O}+\mathrm{h}^{+} \rightarrow \mathrm{OH}+\mathrm{H}^{+}
\end{aligned}
$$

Dyes $+\left(\mathrm{O}_{2}^{-} / \cdot \mathrm{OH} / \mathrm{H}_{2} \mathrm{O}_{2}\right) \rightarrow$ Degraded water pollutant 

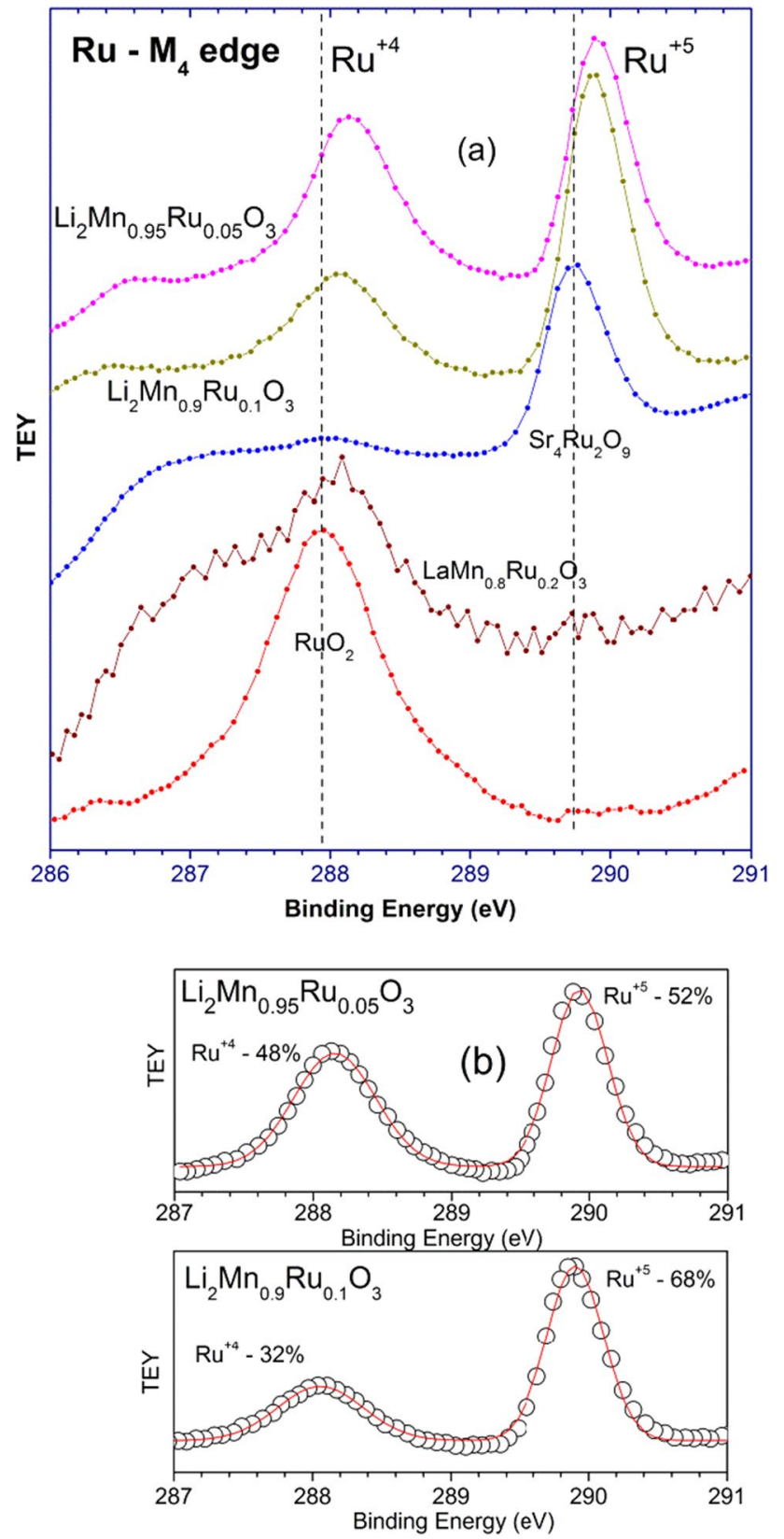

Fig. 7 a XAS spectra of $\mathrm{M}_{4}$ edge for $\mathrm{Li}_{2} \mathrm{Mn}_{1-\mathrm{x}} \mathrm{Ru}_{\mathrm{x}} \mathrm{O}_{3}[\mathrm{x}=0.05,0.1]$. XAS spectra of $\mathrm{RuO}_{2}$ and $\mathrm{Sr}_{4} \mathrm{Ru}_{2} \mathrm{O}_{9}$ used for reference of $\mathrm{Ru}^{+4}$ and $\mathrm{Ru}^{+5}$ valence states peaks. b Fitting of Ru-XAS spectra shows the percentage of $\mathrm{Ru}^{+4}$ and $\mathrm{Ru}^{+5}$ valence states. Circles show the experimental data and red line shows the final peak sum of fit on experimental data

It has been shown that cationic additive enhances the degradation capability of $\mathrm{Li}_{2} \mathrm{MnO}_{3}$. These cations make positive surface of $\mathrm{Li}_{2} \mathrm{MnO}_{3}$ and prevent electron-hole recombination which help generation of. $\mathrm{OH}$ on the $\mathrm{Li}_{2} \mathrm{MnO}_{3}$ surface [40]. We have selected two different type of dyes, (i) A cationic dye, Methylene Blue (MB) and (ii) an azo dye methyl orange (MO) for degradation capabilities of $\mathrm{Li}_{2} \mathrm{MnO}_{3}$ and its $\mathrm{Ru}$ doped compositions. $\mathrm{MB}$ is used for printing, leather and in dyeing cotton and, causes various harmful effects such as eye burns, irritation to the skin and gastrointestinal tract [41]. MB is also regarded as significant threat due to its carcinogenic and mutagenic properties [42]. MB containing waste water from industry is essentially needed an efficient treatment technology which give ultimately clean water for safe disposal quickly. Methyl orange is used as an indicator for acid base titration.

In Figure 11, we have plotted the absorption in the wavelength range $200-800 \mathrm{~nm}$ of (i) as prepared MO solution (ii) $\mathrm{pH}$ controlled $(\mathrm{pH}=6) \mathrm{MO}$ solution and (iii) $\mathrm{MO}$ solution of $\mathrm{pH} 6$ mixed with $\mathrm{Li}_{2} \mathrm{Mn}_{0.9} \mathrm{Ru}_{0.1} \mathrm{O}_{3}$ composition exposed up to $5 \mathrm{~min}$ in visible light. Methyl orange absorbs UV-vis light at $\sim 270 \mathrm{~nm}$ and $\sim 465 \mathrm{~nm}$ which corresponds to $n-\pi^{*}$ transition. MO solution shows absorption peak $\sim 465 \mathrm{~nm}$ which shifts to $\sim 507 \mathrm{~nm}$ after adjusting the $\mathrm{pH} 6$ of the MO solution. After 5 min of ultrasonication and exposure in visible light, $\mathrm{MO}$ solution with $\mathrm{pH} 6$ is degraded and no peaks at $\sim 465$ and $\sim 507 \mathrm{~nm}$ is visible. $\mathrm{Li}_{2} \mathrm{Mn}_{0.9} \mathrm{Ru}_{0.1} \mathrm{O}_{3}$ composition degrades $\mathrm{MO}$ solution $100 \%$ in $5 \mathrm{~min}$ in the presence of nominal $\mathrm{pH} 6$. As prepared $\mathrm{MO}$ solution show no degradation either in sunlight or with ultrasonication (Table 3).

In Figure 12, we have plotted the absorption of the MB solution mixed with $\mathrm{Li}_{2} \mathrm{Mn}_{0.9} \mathrm{Ru}_{0.1} \mathrm{O}_{3}$ composition varied time (b) 1 min (c) 2 min (d) 3 min exposure in visible light. Methylene blue show absorption band at high energy due to $\pi-\pi^{*}$ transition of benzene ring while low energy band $\sim 660-670 \mathrm{~nm}$ corresponds to $n-\pi^{*}$ transitions (where $n$ is the free doublet on the nitrogen atom of $\mathrm{C}=\mathrm{N}$ bond and free doublet of $\mathrm{S}$ atom on $\mathrm{S}=\mathrm{C}$ bond). Insets show the zoomed plot in the wavelength range 400 to $800 \mathrm{~nm}$ for corresponding time exposure in visible light. After $1 \mathrm{~min}$ of exposure in visible light, MB peak $(\lambda=663 \mathrm{~nm})$ shifts to $619 \mathrm{~nm}$ and absorption is very much decreased. After 3 min exposure of visible light, $M B$ is degraded. As prepared MB solution shows no degradation with ultrasonication (Table 4). We have also recorded the degradation using MB solutions ( $\mathrm{pH} 6$ ) exposed in Tungston bulb light for 60 min each with (b) $\mathrm{Li}_{2} \mathrm{MnO}_{3}$, where $\mathrm{Mn}$ is present in +4 valence state (c) $\mathrm{LiMn}_{2} \mathrm{O}_{4}$, where $\mathrm{Mn}$ is present in +3 and +4 valence states and (d) $\mathrm{MnO}_{2}$, where $\mathrm{Mn}$ is present in +4 valence state. We have found that there is no substantial degradation of $\mathrm{MB}$ solution with $\mathrm{Li}_{2} \mathrm{MnO}_{3}$ and LiMn $\mathrm{O}_{4}$ while $\mathrm{MnO}_{2}$ degrades partially in $60 \mathrm{~min}$.

In Figure 13, we show the efficiency for $\mathrm{MB}$ in presence of (i) $\mathrm{Li}_{2} \mathrm{Mn}_{0.9} \mathrm{Ru}_{0.1} \mathrm{O}_{3}$, where $\mathrm{Mn}$ is present in mixed valence 
Fig. 8 a Impedance b capacitance versus frequency plots for $\mathrm{Li}_{2} \mathrm{Mn}_{1-\mathrm{x}} \mathrm{Ru}_{\mathrm{x}} \mathrm{O}_{3}[\mathrm{x}=0.0,0.05$, $0.1]$ compositions

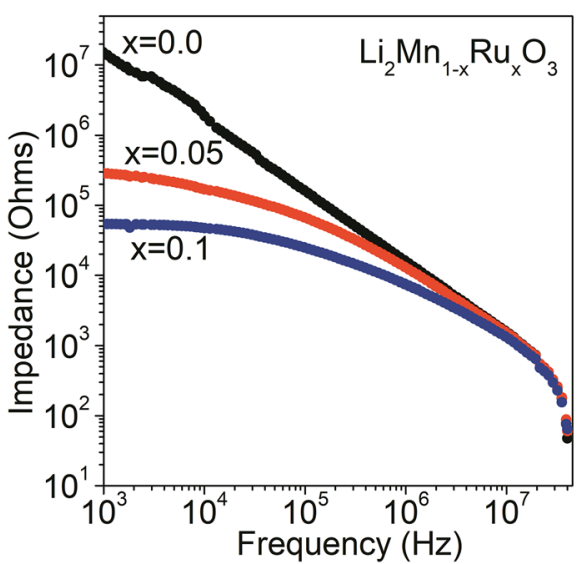

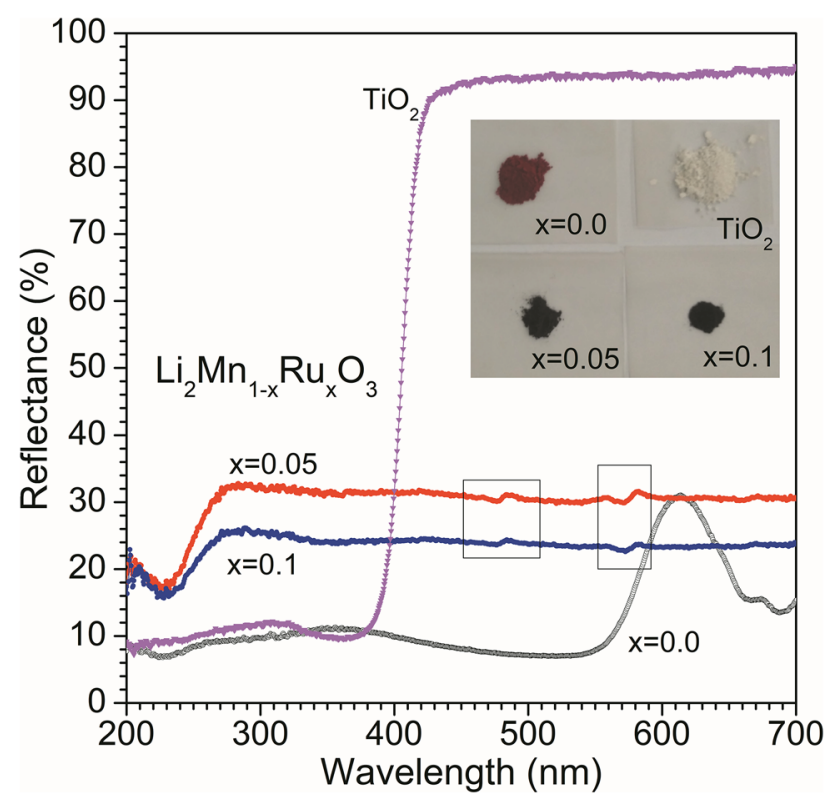

Fig. 9 UV-vis (DRS) spectra for $\mathrm{Li}_{2} \mathrm{Mn}_{1-\mathrm{x}} \mathrm{Ru}_{\mathrm{x}} \mathrm{O}_{3}[\mathrm{x}=0.0,0.05,0.1]$ compositions. $\mathrm{TiO}_{2}$ used as a reference

state +3 and +4 , and $R u$ is in mixed valence state $+4 /+5$ (ii) $\mathrm{Li}_{2} \mathrm{MnO}_{3}$, where $\mathrm{Mn}$ is present in +4 valence state and (iii) $\mathrm{LiMn}_{2} \mathrm{O}_{4}$ where $\mathrm{Mn}$ is present in +3 and +4 valence states. $\mathrm{Li}_{2} \mathrm{Mn}_{0.9} \mathrm{Ru}_{0.1} \mathrm{O}_{3}$ (Mixed valences containing oxide) shows very fast decomposition of Methylene blue at nominal $\mathrm{pH}$ 6 , which was not observed with this efficiency earlier in this type of crystalline materials [40].

Synchrotron X-ray diffraction analysis and Raman spectroscopy measurements show the change in structure with the doping of $\mathrm{Ru}$ at $\mathrm{Mn}$ site in $\mathrm{Li}_{2} \mathrm{Mn}_{1-\mathrm{x}} \mathrm{Ru}_{\mathrm{x}} \mathrm{O}_{3}$ $[x=0.05,0.1]$. XRD studies show the change in lattice which suggest the presence of Ru with $\mathrm{Mn}$ in the lattice of $\mathrm{Li}_{2} \mathrm{Mn}_{1-\mathrm{x}} \mathrm{Ru}_{\mathrm{x}} \mathrm{O}_{3}[\mathrm{x}=0.05,0.1]$ systems. XAS studies show the presence of $\mathrm{Ru}^{+4} / \mathrm{Ru}^{+5}$ and $\mathrm{Mn}^{+3} / \mathrm{Mn}^{+4}$ redox couples in Ru doped materials. When $\mathrm{Ru}^{+4}$ doped at $\mathrm{Mn}^{+4}$ site, due to comparable redox potential of $\mathrm{Ru}^{+4} / \mathrm{Ru}^{+5}$ $(1.07 \mathrm{eV})$ with that of $\mathrm{Mn}^{+3} / \mathrm{Mn}^{+4}(1.02 \mathrm{eV}), \mathrm{Ru}^{+4}(0.62 \AA)$ converts into $\mathrm{Ru}^{+5}(0.565 \AA)$ and for charge valence same amount of $\mathrm{Mn}^{+4}(0.53 \AA)$ converts into $\mathrm{Mn}^{+3}(0.645 \AA$ ) [11, 15]. When $\mathrm{Ru}^{+4}$ doped at $\mathrm{Mn}^{+3}$ site in $\mathrm{LaMnO}_{3}$ then mixed valence is not observed as shown in Fig. 7 and it also show by patra et al. [21]. It has been shown earlier that $\mathrm{Mn}^{+3}(0.645 \AA$ ) (in octahedral coordinated configuration) has comparatively bigger radius than $\mathrm{Mn}^{+4}(0.53 \AA)$ and it has an electron in $\mathrm{e}_{g}$ orbital. Due to one $e_{g}$ electron, $\mathrm{Mn}^{+3}-\mathrm{O}_{6}$ octahedral elongate in $\mathrm{z}$ axis direction and it brings distortion in lattice. Although, the presence of $\mathrm{Ru}^{+5}(0.565 \AA$ ) make up charge balance but due to size mismatch with $\mathrm{Mn}^{+3}(0.645 \AA$ ) could not stop distortion in lattice of $\mathrm{Li}_{2} \mathrm{Mn}_{1-x} \mathrm{Ru}_{\mathrm{x}} \mathrm{O}_{3}[\mathrm{x}=0.05,0.1]$. Raman and IR spectroscopic studies show the evidence of lattice distortion by changing the peak position and splitting in $\mathrm{Ru}$ doped compositions.

Impedance has been observed $10^{2}$ times less in $\mathrm{Li}_{2} \mathrm{Mn}_{0.9} \mathrm{Ru}_{0.1} \mathrm{O}_{3}$ in comparison to that of $\mathrm{Li}_{2} \mathrm{MnO}_{3}$ due to the bigger $\mathrm{d}$ orbitals of $\mathrm{Ru}$ in comparison to $\mathrm{Mn}$ and mixed valences $\mathrm{Ru}^{+4} / \mathrm{Ru}^{+5}$ and $\mathrm{Mn}^{+3} / \mathrm{Mn}^{+4}$. Electrons can easily hope in $\mathrm{Ru}$ assisted invironment in $\mathrm{Li}_{2} \mathrm{Mn}_{1-\mathrm{x}} \mathrm{Ru}_{\mathrm{x}} \mathrm{O}_{3}$ in comparison to $\mathrm{Li}_{2} \mathrm{MnO}_{3} . \mathrm{Mn}^{+3}$ contains 3 electrons in $t_{2 g}$ orbitals while 1 electron in $e_{g}$ orbitals while $\mathrm{Mn}^{+4}$ contains only 3 electrons in $\mathrm{t}_{2 g}$ orbitals. $\mathrm{Ru}^{+4}$ contains 2 paired and 2 unpaired electrons in $\mathrm{t}_{2 \mathrm{~g}}$ orbitals while $\mathrm{Ru}^{+5}$ contains only 3 electrons in $t_{2 g}$ orbitals. One $e_{g}$ electron of $\mathrm{Mn}^{+3}$ can hope to vacant $\mathrm{e}_{\mathrm{g}}$ orbitals $\mathrm{Mn}^{+4}$ and $\mathrm{Ru}^{+5}$ in $\mathrm{Ru}$ doped $\mathrm{Li}_{2} \mathrm{MnO}_{3}$ compositions. One e electron of $\mathrm{Mn}^{+3}$ and presence of $4 \mathrm{~d}$ orbitals containing Ru modify the impedance and capacitance properties of $\mathrm{Ru}$ doped $\mathrm{Li}_{2} \mathrm{MnO}_{3}$ compositions. 
Fig. 10 Band gap calculations using UV-vis (DRS) spectra for a $F(R)$ for all the compositions b $x=0.0, \mathbf{c x}=0.05 \mathbf{d x}=0.1$ in $\mathrm{Li}_{2} \mathrm{Mn}_{1-\mathrm{x}} \mathrm{Ru}_{\mathrm{x}} \mathrm{O}_{3}[\mathrm{x}=0.0,0.05$, 0.1 ] compositions
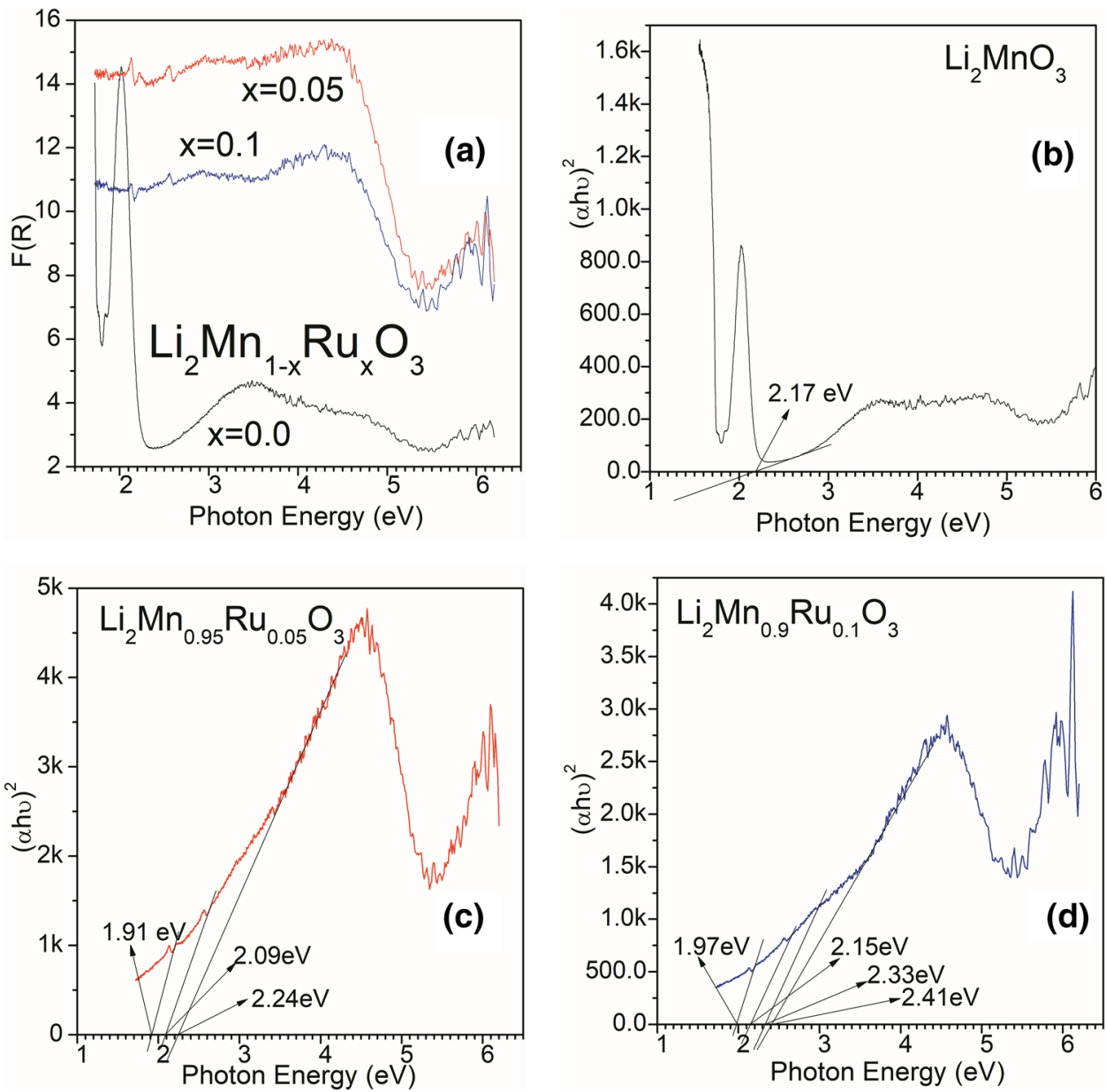

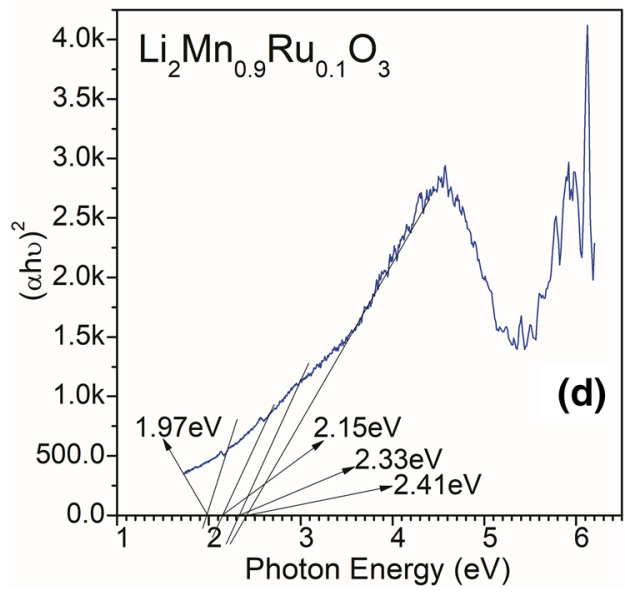

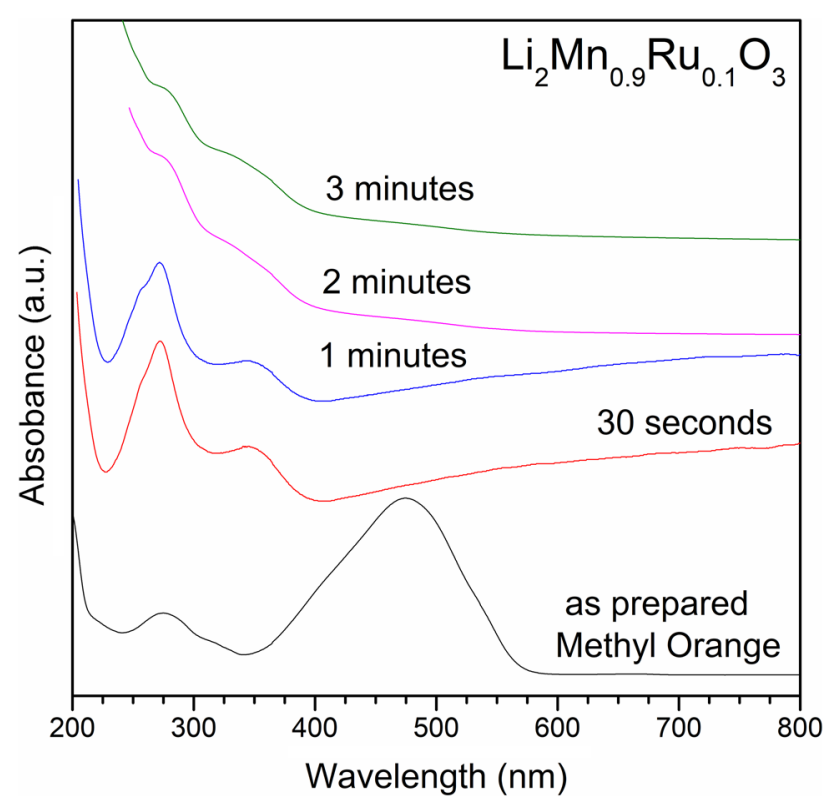

Fig. 11 Absorbance spectra of the Methyl Orange solutions after reaction with $\mathrm{Li}_{2} \mathrm{Mn}_{0.9} \mathrm{Ru}_{0.1} \mathrm{O}_{3}$ in the given exposure time of $\mathrm{W}$ bulb light. Please note disappearance of peak $\sim 450 \mathrm{~nm}$ on $30 \mathrm{~s}$ of exposure of $\mathrm{W}$ bulb light
Diffuse reflectance spectroscopic studies suggest the optical absorption in visible light in $\mathrm{Li}_{2} \mathrm{Mn}_{1-x} \mathrm{Ru}_{\mathrm{x}} \mathrm{O}_{3}[\mathrm{x}=0.0$, $0.05,0.1]$ systems. Band gap increases with the increase of Ru content while crystallite size decreased. In the crystalline environment of $\mathrm{Ru}$ and $\mathrm{Mn}$ in $\mathrm{Li}_{2} \mathrm{Mn}_{1-\mathrm{x}} \mathrm{Ru}_{\mathrm{x}} \mathrm{O}_{3}$ $[x=0.05,0.1], M n$ intersite and Ru intersite transitions using $e_{g}-e_{g}, t_{2 g}-e_{g}$ may become allowed by spin orbit coupling, lattice disorder/distortions and mixing of odd parity wave functions. Decreases in crystallite size of the compositions, $\mathrm{Mn}-\mathrm{Mn}$ intersite, Ru-Mn intersite and spin orbit coupling are the main cause of enhanced band gap of $\mathrm{Li}_{2} \mathrm{Mn}_{0.9} \mathrm{Ru}_{0.1} \mathrm{O}_{3}$ and $\mathrm{Li}_{2} \mathrm{Mn}_{0.95} \mathrm{Ru}_{0.05} \mathrm{O}_{3}$ in comparison to $\mathrm{Li}_{2} \mathrm{MnO}_{3}$.

Presence of mixed valences $\mathrm{Ru}^{+4} / \mathrm{Ru}^{+5}$ and $\mathrm{Mn}^{+3} / \mathrm{Mn}^{+4}$ assist the process of degradation of $\mathrm{MO}$ and $\mathrm{MB}$ solutions with faster rate in comparison with $\mathrm{MnO}_{2}$. Compounds $\mathrm{LaMn}_{1-\mathrm{x}} \mathrm{Ru}_{\mathrm{x}} \mathrm{O}_{3}$ degrades $\mathrm{MO}$ dye only at $\mathrm{pH} 2.5$ and takes 15 min [21]. $\mathrm{LaMn}_{1-\mathrm{x}} \mathrm{Ru}_{\mathrm{x}} \mathrm{O}_{3}$ shows the presence of only $\mathrm{Mn}^{+3}$ and $\mathrm{Ru}^{+4}$ valence states. Our results show the presence of redox couples $\mathrm{Mn}^{+3}-\mathrm{Mn}^{+4}$ and $\mathrm{Ru}^{+4}-\mathrm{Ru}^{+5}$ valence states in $\mathrm{Li}_{2} \mathrm{Mn}_{1-\mathrm{x}} \mathrm{Ru}_{\mathrm{x}} \mathrm{O}_{3}[\mathrm{x}=0.05,0.1$,$] . Multiple valence$ states enhance the process of degradation of $5 \mathrm{ml}$ each of $\mathrm{MO}$ and $\mathrm{MB}$ dyes in $\mathrm{Li}_{2} \mathrm{Mn}_{1-\mathrm{x}} \mathrm{Ru}_{\mathrm{x}} \mathrm{O}_{3}[\mathrm{x}=0.05,0.1] ,.5 \mathrm{mg}$ of 
Table 3 Degradation profile of Methyl Orange (MO) dye with $\mathrm{Li}_{2} \mathrm{Mn}_{1-\mathrm{x}} \mathrm{Ru}_{\mathrm{x}} \mathrm{O}_{3}$ and $\mathrm{MnO}_{2}$ in different experimental conditions

\begin{tabular}{lll}
\hline Conditions for methyl orange (MO) degradation & \multicolumn{2}{l}{ Degradation time with compounds } \\
\cline { 2 - 3 } & $\mathrm{Li}_{2} \mathrm{Mn}_{0.9} \mathrm{Ru}_{0.1} \mathrm{O}_{3}$ & $\mathrm{Li}_{2} \mathrm{MnO}_{3}$ \\
\hline In the presence of sunlight (solution pH-6) & $\sim 5 \mathrm{~min}$ & $\sim 30 \mathrm{~min}$ \\
In the presence of sunlight (as prepared solution) & No degradation in $1 \mathrm{~h}$ & No degradation in $1 \mathrm{~h}$ \\
Ultrasonicated in W bulb light (solution pH-6) & $\sim 3 \mathrm{~min}$ & $\sim 60 \mathrm{~min}$ \\
Without ultrasonication exposed in W bulb (solution $\mathrm{pH}-6)$ & $\sim 5 \mathrm{~min}$ & $\sim 60 \mathrm{~min}$ \\
Ultrasonicated in W bulb (as prepared solution) & No Degradation in $1 \mathrm{~h}$ & No degradation in $1 \mathrm{~h}$ \\
Ultrasonicated in dark (absence of light) solution $\mathrm{pH}-6$ & 30 min & $\sim 60$ min \\
\hline
\end{tabular}

$\mathrm{Li}_{2} \mathrm{Mn}_{0.9} \mathrm{Ru}_{0.1} \mathrm{O}_{3}$ degrades $5 \mathrm{ml}$ of $\mathrm{MO}(10 \mathrm{mg} / \mathrm{L})$ up to $100 \%$ in $5 \mathrm{~min}$ and $5 \mathrm{ml}$ of $\mathrm{MB}(10 \mathrm{mg} / \mathrm{L})$ in $3 \mathrm{~min}$ at $\mathrm{pH} 6.5 \mathrm{mg}$ of $\mathrm{MnO}_{2}$ does not degrade $5 \mathrm{ml}$ of $\mathrm{MO}(10 \mathrm{mg} / \mathrm{L})$ in $60 \mathrm{~min}$ and $5 \mathrm{ml}$ of $\mathrm{MB}(10 \mathrm{mg} / \mathrm{L})$ in $60 \mathrm{~min}$ at $\mathrm{pH}$ 6[Tables 3,4; Fig. 13]. $20 \mathrm{mg}$ of flower like $\mathrm{Mn}_{3} \mathrm{O}_{4}$ (where $\mathrm{Mn}$ in $\mathrm{Mn}^{+3}$ valence state) degrades $50 \mathrm{ml} \mathrm{MB}(10 \mathrm{mg} / \mathrm{L})$ up to $80 \%$ in $180 \mathrm{~min}$ in presence of $\mathrm{H}_{2} \mathrm{O}_{2}$ [8]. $100 \mathrm{mg}$ nano wires of $\mathrm{MnO}_{2}$ (where $\mathrm{Mn}$ in $\mathrm{Mn}^{+4}$ valence state) degrades $200 \mathrm{ml}$ $\mathrm{MO}$ (40 mg/L) up to $100 \%$ in $90 \mathrm{~min}$ [9].

Possible degradation mechanism can be summarised by following reactions as shown by Ranjeh et al.:

$$
\begin{aligned}
& \text { Methylene Blue/Methyl Orange Dye }+\left(\mathrm{O}_{2}^{-} / \cdot \mathrm{OH} / \mathrm{H}_{2} \mathrm{O}_{2}\right) \\
& \quad \rightarrow \text { Degraded water pollutant }
\end{aligned}
$$

Presence of multiple valence states $\mathrm{Mn}^{+3} / \mathrm{Mn}^{+4}$ and $\mathrm{Ru}^{+4} / \mathrm{Ru}^{+5}$ create photo generated electrons and holes by transferring electrons from valence band to conduction band leaving holes in valence band. Electrons react with $\mathrm{O}_{2}$ and generate $\mathrm{O}_{2}^{-} . \mathrm{O}_{2}^{-}$further reacts with $\mathrm{H}^{+}$ions and generates $\mathrm{H}_{2} \mathrm{O}_{2}$. Holes react with $\mathrm{OH}^{-}$and generate $\mathrm{OH}^{\circ}$ free radicals. So $\left(\mathrm{O}_{2}^{-} / . \mathrm{OH} / \mathrm{H}_{2} \mathrm{O}_{2}\right)$ react with $\mathrm{MO}, \mathrm{MB}$ dyes solution and decolourize. If $\mathrm{H}^{+}$ions are not present then these compounds does not degrade $\mathrm{MO}$ and $\mathrm{MB}$ dyes. In presence of $\mathrm{H}^{+}$and visible light, $\mathrm{Li}_{2} \mathrm{MnO}_{3}$ does not degrade $\mathrm{MO}$ and $\mathrm{MB}$ dyes up to $24 \mathrm{~h}$. $\mathrm{Li}_{2} \mathrm{Mn}_{1-\mathrm{x}} \mathrm{Ru}_{\mathrm{x}} \mathrm{O}_{3}[\mathrm{x}=0.05,0.1]$ degrades $\mathrm{MO}$ and $\mathrm{MB}$ dyes very fast in presence of $\mathrm{H}^{+}$ $(\mathrm{pH} \mathrm{6)}$ and $\mathrm{W}$ bulb/sunlight due to presence of mixed valence states $\mathrm{Mn}^{+3} / \mathrm{Mn}^{+4}$ and $\mathrm{Ru}^{+4} / \mathrm{Ru}^{+5}$. These materials degrades $\mathrm{MB}$ dye very fast in compare to other $\mathrm{Mn}$ based systems $\mathrm{Mn}_{3} \mathrm{O}_{4}, \mathrm{MnO}_{2}$ and nano $\mathrm{Li}_{2} \mathrm{MnO}_{3}[8,9,43]$. Easy material preparation of $\mathrm{Li}_{2} \mathrm{Mn}_{1-\mathrm{x}} \mathrm{Ru}_{\mathrm{x}} \mathrm{O}_{3}$ and reusability of these materials is an advantage over other known $\mathrm{TiO}_{2}$ based catalysts.

\section{Conclusions}

We have optimized the synthesis conditions for inducing the redox interaction between $\mathrm{Ru}^{+4}$ and $\mathrm{Mn}^{+4}$ which further results $\mathrm{Mn}^{+3}-\mathrm{Mn}^{+4}$ and $\mathrm{Ru}^{+4}-\mathrm{Ru}^{+5}$ valence states in $\mathrm{Li}_{2} \mathrm{Mn}_{1-x} \mathrm{Ru}_{x} \mathrm{O}_{3}[\mathrm{x}=0.05,0.1]$. These redox couples in presence of $\mathrm{H}^{+}$ions and $\mathrm{W}$ bulb/sunlight enhances the dye degradation process in $\mathrm{Ru}$ doped $\mathrm{Li}_{2} \mathrm{MnO}_{3}$. $\mathrm{Li}_{2} \mathrm{Mn}_{0.9} \mathrm{Ru}_{0.1} \mathrm{O}_{3}$ composition (i) shows $10^{2}$ times decreased impedance and (ii) quickly degrades methyl orange and methylene blue solutions at $\mathrm{pH} 6$ which shows its capability as effective dye degradation material which otherwise was neither found in other $\mathrm{Mn}$ based systems nor in these types of monoclinic crystals. These Ru doped $\mathrm{Li}_{2} \mathrm{Mn}_{1-\mathrm{x}} \mathrm{Ru}_{\mathrm{x}} \mathrm{O}_{3}$ materials can be use for fast decomposition of other organic dyes which are harmful for environment. Fast degradation of dyes, easy material preparation and reusability can make these materials first choice in industry over other known $\mathrm{TiO}_{2}$ based catalysts. 
Fig. 12 Absorption spectra of the MB solutions during the decomposition reaction catalyzed by $\mathrm{Li}_{2} \mathrm{Mn}_{0.9} \mathrm{Ru}_{0.1} \mathrm{O}_{3}$ in the exposure of visible light for (b) 1 (c) 2 and (d) 3 min

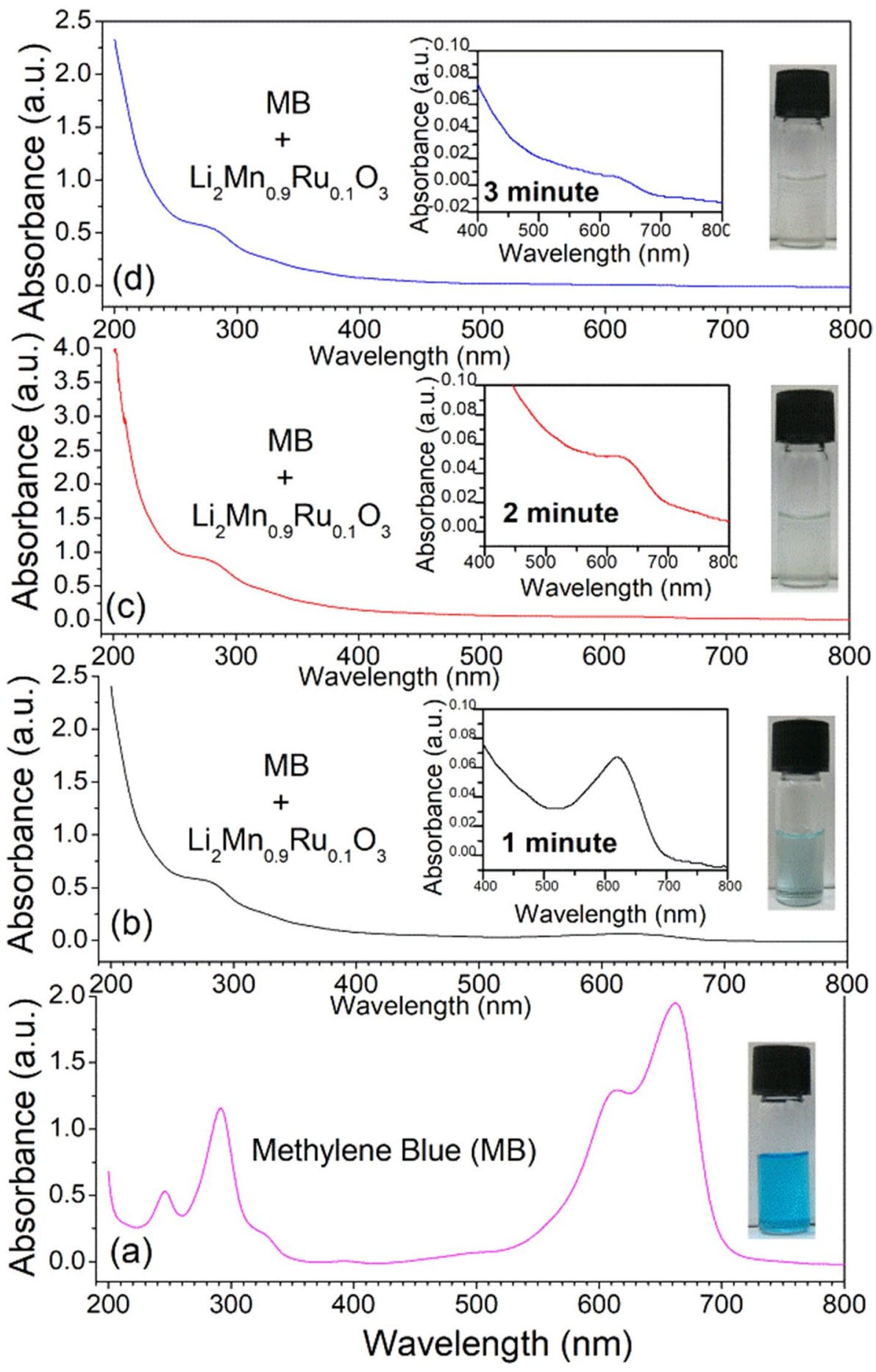


Table 4 Degradation profile of methylene blue (MB) dye with $\mathrm{Li}_{2} \mathrm{Mn}_{1-\mathrm{x}} \mathrm{Ru}_{\mathrm{x}} \mathrm{O}_{3}$ and $\mathrm{MnO}_{2}$ in different experimental conditions

Conditions for Methylene Blue (MB) degradation Degradation time with compounds

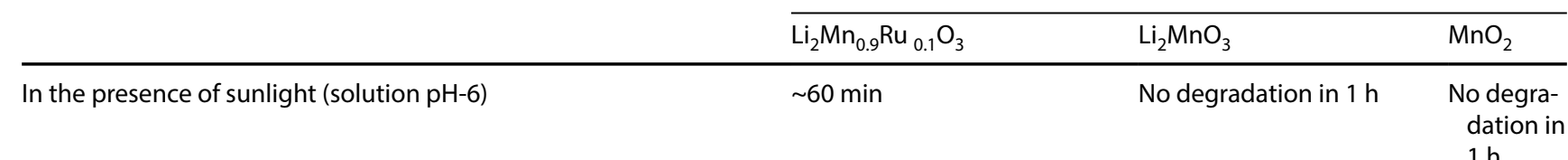

In the presence of sunlight (as prepared solution)

Ultrasonicated in W bulb light (solution $\mathrm{pH}-6$ )

Without ultrasonication exposed in W bulb light (solution $\mathrm{pH}-6$ )

Ultrasonicated in W bulb light (as prepared solution)

Ultrasonicated in dark (absence of light) solution $\mathrm{pH}-6$
Partial degradation in $1 \mathrm{~h}$

$\sim 3 \mathrm{~min}$

$\sim 60 \mathrm{~min}$

No degradation in $2 \mathrm{~h}$

$\sim 30 \mathrm{~min}$
No degradation in $1 \mathrm{~h}$

No degradation in $2 \mathrm{~h}$

$2 \mathrm{~h}$

No com-

plete

degra-

dation in

$2 \mathrm{~h}$

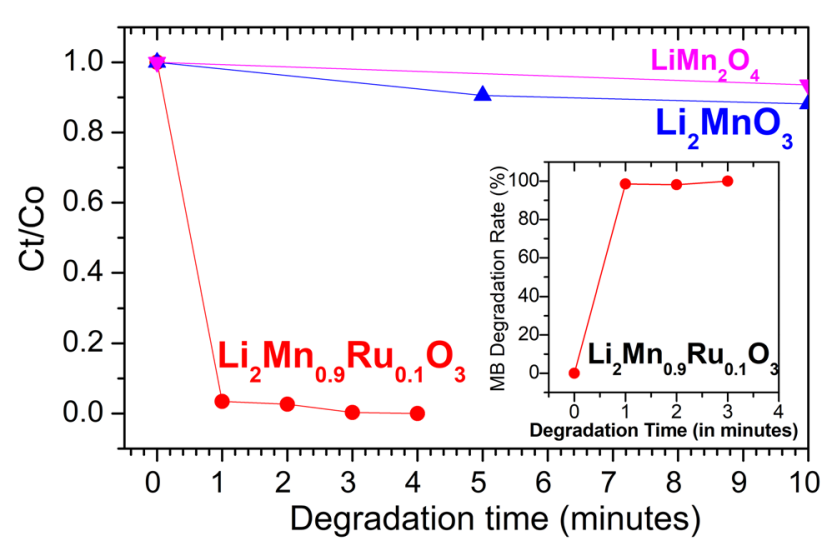

Fig. 13 Degradation rate of $\mathrm{MB}$ solutions $[5 \mathrm{ml}$ of $10 \mathrm{mg} / \mathrm{L}$ concentration] under visible light irradiation with $5 \mathrm{mg} \mathrm{Li}{ }_{2} \mathrm{Mn}_{0.9} \mathrm{Ru}_{0.1} \mathrm{O}_{3}$, $\mathrm{Li}_{2} \mathrm{MnO}_{3}$ and $\mathrm{LiMn}_{2} \mathrm{O}_{4}$ each

Acknowledgements P. Singh thanks to the UGC-DAE-Consortium for Scientific Research (CSR), Indore Centre for project fellowship and B. Singh thanks for providing financial support under the CRS project scheme. B. Singh thanks Department of Science and Technology, India for the financial support and Saha Institute of Nuclear Physics, India for facilitating the experiments at the Indian Beamline, Photon Factory, KEK, Japan. B. Singh thanks to Dr. Mukul Gupta (UGC-DAECSR Indore), Dr. D. M. Phase (UGC-DAE-CSR Indore) for help in SXAS experiments and Prof. R. Dhar (Univ. of Allahabad) for UV-visible spectroscopy measurements.

\section{Compliance with ethical standards}

Conflict of interest The authors declare "There are no conflicts to declare".

\section{References}

1. Ellis BL, Lee KT, Nazar LF (2010) Positive electrode materials for Li-ion and Li-batteries. Chem Mater 22:691-714
2. Coey JMD, Viret M, Molnar VS (1999) Mixed-valence manganites. Adv Phys 48:167-293

3. Weifeng W, Xinwei C, Weixing C, Douglas GI (2011) Manganese oxide-based materials as electrochemical supercapacitor electrodes. Chem Soc Rev 40:1697-1721

4. Thackeray MM, David WIF, Bruce PG, Goodenough JB (1983) Lithium insertion into manganese spinels. Mater Res Bull 18:461-472

5. Jin S, Tiefel TH, McCormack M, Fastnacht RA, Ramesh R, Chen LH (1994) Colossal magnetoresistance in La-Ca-Mn-O ferromagnetic thin films. Science 264:413-415

6. Millis AJ, Shraiman BI, Mueller R (1996) Dynamic Jahn-Teller effect and colossal magnetoresistance in $\mathrm{La}_{1-\mathrm{x}} \mathrm{Sr}_{\mathrm{x}} \mathrm{MnO}_{3}$. Phys Rev Lett 77:175-178

7. Tarascon JM, McKinnon WR, Coowar F, Bowmer TN, Amatucci G, Guyomard D (1994) Structural stability of $\mathrm{LiMn}_{2} \mathrm{O}_{4}$ electrodes for lithium batteries. J Electrochem Soc 141:1421-1431

8. Wang Y, Zhu L, Yang X, Shao E, Deng X, Liu N, Wu M (2015) Facile synthesis of three-dimensional $\mathrm{Mn}_{3} \mathrm{O}_{4}$ hierarchical microstructures and their application in the degradation of methylene blue. J Mater Chem A 3:2934-2941

9. Yin B, Zhang S, Jiao Y, Liu Y, Qu F, Wu X (2014) Facile synthesis of ultralong $\mathrm{MnO}_{2}$ nanowires as high performance supercapacitor electrodes and photocatalysts with enhanced photocatalytic activities. Cryst Eng Comm 16:9999-10005

10. Yoo SH, Jang D, Johab HIK, Lee S (2017) Iron oxide/porous carbon as a heterogeneous Fenton catalyst for fast decomposition of hydrogen peroxide and efficient removal of methylene blue. J Mater Chem A 5:748-755

11. Sahu RK, Hu Z, Rao ML, Manoharan SS, Schmidt T, Richter B, Knupfer M, Golden M, Fink J, Schneider CM (2002) X-ray absorption spectra at the $\mathrm{Ru}$ and $M n \mathrm{~L}_{2,3}$ edges and long-range ferromagnetism in $\mathrm{SrRu}_{1-\mathrm{x}} \mathrm{Mn}_{\mathrm{x}} \mathrm{O}_{3}$ solid solutions $(0 \leq \mathrm{x} \leq 0.5)$. Phys Rev B 66:144415

12. Reddy MV, Manoharan SS, John J, Singh B, Rao GVS, Chowdari BVR (2009) Synthesis, characterization, and electrochemical cycling behavior of the Ru-doped spinel, $\mathrm{Li}\left[\mathrm{Mn}_{2-\mathrm{x}} \mathrm{Ru}_{\mathrm{x}}\right] \mathrm{O} 4(\mathrm{x}=0$, 0.1 , and 0.25). J Electrochem Soc 156:A652-A660

13. Malavasi L, Mozzati MC, Tealdi C, Azzoni CB, Flor G (2005) Influence of Ru doping on the structure, defect chemistry, magnetic interaction, and carrier motion of the $\mathrm{La}_{1-x} \mathrm{Na}_{x} \mathrm{MnO}_{3+\text { delta }}$ manganite. J Phys Chem B 109:20707-20713

14. Singh B, Manoharan SS, Rao ML, Pai SP (2004) Long range ferromagnetic ordering in pulsed laser deposited $\mathrm{La}_{0.7} \mathrm{Ca}_{0.3} \mathrm{Mn}_{1-\mathrm{x}} \mathrm{Ru}_{\mathrm{x}} \mathrm{O}_{3}$ thin films. Phys Chem Chem Phys 6:4199-4202 
15. Manoharan SS, Sahu RK (2002) Evidence for an anomalous redox ionic pair between $\mathrm{Ru}$ and $\mathrm{Mn}$ in $\mathrm{SrRu}_{0.5} \mathrm{Mn}_{0.5} \mathrm{O}_{3}$ : an $\mathrm{X}$-ray absorption spectroscopy approach. Chem Commun 24:3068-3069

16. Mori D, Sakaebeb H, Shikanob M, Kojitania H, Tatsumib K, Inaguma Y (2011) Synthesis, phase relation and electrical and electrochemical properties of ruthenium-substituted $\mathrm{Li}_{2} \mathrm{MnO}_{3}$ as a novel cathode material. J Power Sources 196:6934-6938

17. Sathiya $M$, Ramesha $K$, Rousse $G$, Foix $D$, Gonbeau D, Prakash AS, Doublet ML, Hemalatha K, Tarascon JM (2013) High performance $\mathrm{Li}_{2} \mathrm{Ru}_{1-\mathrm{y}} \mathrm{Mn}_{\mathrm{y}} \mathrm{O}_{3}(0.2 \leq \mathrm{y} \leq 0.8)$ cathode materials for rechargeable lithium-ion batteries: their understanding. Chem Mater 25:1121-1131

18. Xu Y, Hu E, Yang F, Corbett J, Sun Z, Lyu Y, Yu X, Liu Y, Yang XQ, Li H (2016) Structural integrity - searching the key factor to suppress the voltage fade of Li-rich layered cathode materials through 3D X-ray imaging and spectroscopy techniques. Nano Energy 28:164-171

19. Sathiya M, Rousse G, Ramesha K, Laisa CP, Vezin H, Sougrati MT, Doublet ML, Foix D, Gonbeau D, Walker W, Prakash AS, Hassine MB, Dupont L, Tarascon JM (2013) Reversible anionic redox chemistry in high-capacity layered-oxide electrodes. Nat Mater 12:827-835

20. Singh $\mathrm{B}$ (2016) $\mathrm{Ru}^{4+}$ induced colossal magnetoimpedance in $\mathrm{Ru}$ doped perovskite manganite at room temperature. Phys Chem Chem Phys 18:12947-12951

21. Patra AS, Gogoi G, Sahu RK, Qureshi M (2017) Modulating the electronic structure of lanthanum manganite by ruthenium doping for enhanced photocatalytic water oxidation. Phys Chem Chem Phys 19:12167-12174

22. Kubelka P, Munk F (1931) Ein Beitrag Zur Optik Der Farbanstriche. Z Techn Phys 12:593-601

23. Tauc J (1968) Optical properties and electronic structure of amorphous Ge and Si. Mater Res Bull 3:37-46

24. Strobel P, Lambert-Andron B (1988) Crystallographic and magnetic structure of $\mathrm{Li}_{2} \mathrm{MnO}_{3}$. J Solid State Chem 75:90-98

25. Massarotti V, Bini M, Capsoni D, Altomare A, Moliterni AGG (1997) $\mathrm{Ab}$ initio structure determination of $\mathrm{Li}_{2} \mathrm{MnO}_{3}$ from X-ray powder diffraction data. J Appl Crystallogr 30:123-127

26. Singh $B$ (2015) Structural, transport, magnetic and magnetoelectric properties of $\mathrm{CaMn}_{1-\mathrm{x}} \mathrm{Fe}_{\mathrm{x}} \mathrm{O}_{3-\delta}(0.0 \leq \mathrm{x} \leq 0.4)$. RSC Adv 50:39938-39945

27. Ruther RE, Dixit H, Pezeshki AM, Sacci RL, Cooper VR, Nanda J, Veith GM (2015) Correlating local structure with electrochemical activity in $\mathrm{Li}_{2} \mathrm{MnO}_{3}$. J Phys Chem C 119:18022-18029

28. Julien CM, Massot M (2003) Lattice vibrations of materials for lithium rechargeable batteries III. Lithium manganese oxides. Mater Sci Eng, B 100:69-78

29. Amalraj SF, Sharon D, Talianker M, Julien CM, Burkala L, Lavi R, Zhecheva E, Markovsky B, Zinigrad E, Kovacheva D (2013) Study of the nanosized $\mathrm{Li}_{2} \mathrm{MnO}_{3}$ : electrochemical behavior, structure, magnetic properties, and vibrational modes. Electrochim Acta 97:259-270

30. Saroha R, Gupta A, Panwar AK (2017) Electrochemical performances of Li-rich layered-layered $\mathrm{Li}_{2} \mathrm{MnO}_{3}-\mathrm{LiMnO}_{2}$ solid solutions as cathode material for lithium-ion batteries. J Alloys Compd 696:580-589
31. Liu RS, Jang LY, Chen JM, Tsai YC, Hwang YD, Liu RG (1997) X-ray absorption studies in spinel-type $\mathrm{LiMn}_{2} \mathrm{O}_{4}$. J Solid State Chem 128:326-329

32. Hu Z, Lips HV, Golden MS, Fink J, Kaindl G, de Groot FM, Ebbinghaus $S$, Reller $A$ (2000) Multiplet effects in the Ru $L_{2,3}$ X-rayabsorption spectra of $\mathrm{R}(\mathrm{IV})$ and $\mathrm{Ru}(\mathrm{V})$ compounds. Phy Rev $\mathrm{B}$ 61:5262-5266

33. Zhou JG, Fang HT, Hu YF, Sham TK, Wu CX, Liu M, Li F (2009) Immobilization of $\mathrm{RuO}_{2}$ on carbon nanotube: an X-ray absorption near-edge structure study. J Phys Chem C 113:10747-10750

34. Manoharan SS, Singh B, Driscoll J, Branford W, Cohen L, Besmehn A (2005) Magnetism and electronic transport in $\mathrm{Sr}_{4-\mathrm{x}} \mathrm{La}_{\mathrm{x}} \mathrm{Ru}_{2-\mathrm{x}} \mathrm{Mn}_{\mathrm{x}} \mathrm{O}_{9}$ : interplay of $\mathrm{Mn}$ and Ru redox chemistry. J Appl Phys 97:10A304

35. Tamilarasan S, Laha S, Natarajan S, Gopalakrishnan J (2015) $\mathrm{Li}_{2} \mathrm{MnO}_{3}$ : a rare red-coloured manganese (IV) oxide exhibiting tunable red-yellow-green emission. J Mater Chem C 3:4794-4800

36. Xiao R, Li H, Chen L (2012) Density functional investigation on $\mathrm{Li}_{2} \mathrm{MnO}_{3}$. Chem Mater 24:4242-4251

37. Quijada M, Černe J, Simpson JR, Drew HD, Ahn KH, Millis AJ, Shreekala R, Ramesh R, Rajeswari M, Venkatesan T (1988) Optical conductivity of manganites: crossover from Jahn-Teller small polaron to coherent transport in the ferromagnetic state. Phys Rev B 58:16093-16102

38. McCormack M, Jin S, Tiefel TH, Fleming RM, Phillips JM, Ramesh $\mathrm{R}$ (1994) Very large magnetoresistance In perovskite-like La-CaMn-0 thin films. Appl Phys Lett 64:3045-3047

39. Prellier W, Mercey B, Lecouer P (2001) Colossal-magnetoresistive manganite thin films. J Phys: Condens Matter 13:R915-R944

40. Ranjeh M, Masjedi-Arani M, Salavati-Niasari M, Hossein Moayedi $\mathrm{H}$ (2020) EDTA-modified sol-gel synthesis of monoclinic $\mathrm{Li}_{2} \mathrm{MnO}_{3}$ nanoparticles as an effective photocatalyst for degradation of organic dyes. J Mol Liq 300:112292

41. Turhan K, Ozturkcan SA (2013) Decolorization and degradation of reactive dye in aqueous solution by ozonation in a semi-batch bubble column reactor. Water Air Soil Pollut 224:1353

42. El Mouzdahir Y, Elmchaouri A, Mahboub R, Gil A, Korili SA (2010) Equilibrium modeling for the adsorption of methylene blue from aqueous solutions on activated clay minerals. Desalination 250:335-338

43. Larbi T, Doll K, Amlouk M (2019) Temperature dependence of Raman spectra and first principles study of NiMn2O4 magnetic spinel oxide thin films: application in efficient photocatalytic removal of RhB and MB dyes. Spectrochim Acta Part A Mol Biomol Spectrosc 216:117-224

Publisher's Note Springer Nature remains neutral with regard to jurisdictional claims in published maps and institutional affiliations. 